Historic, Archive Document

Do not assume content reflects current scientific knowledge, policies, or practices. 


\section{THE VAN DUSEN NURSERIES}

$7800 \%$

Geneva, N. Y.

W. L. McKAY, Proprietor

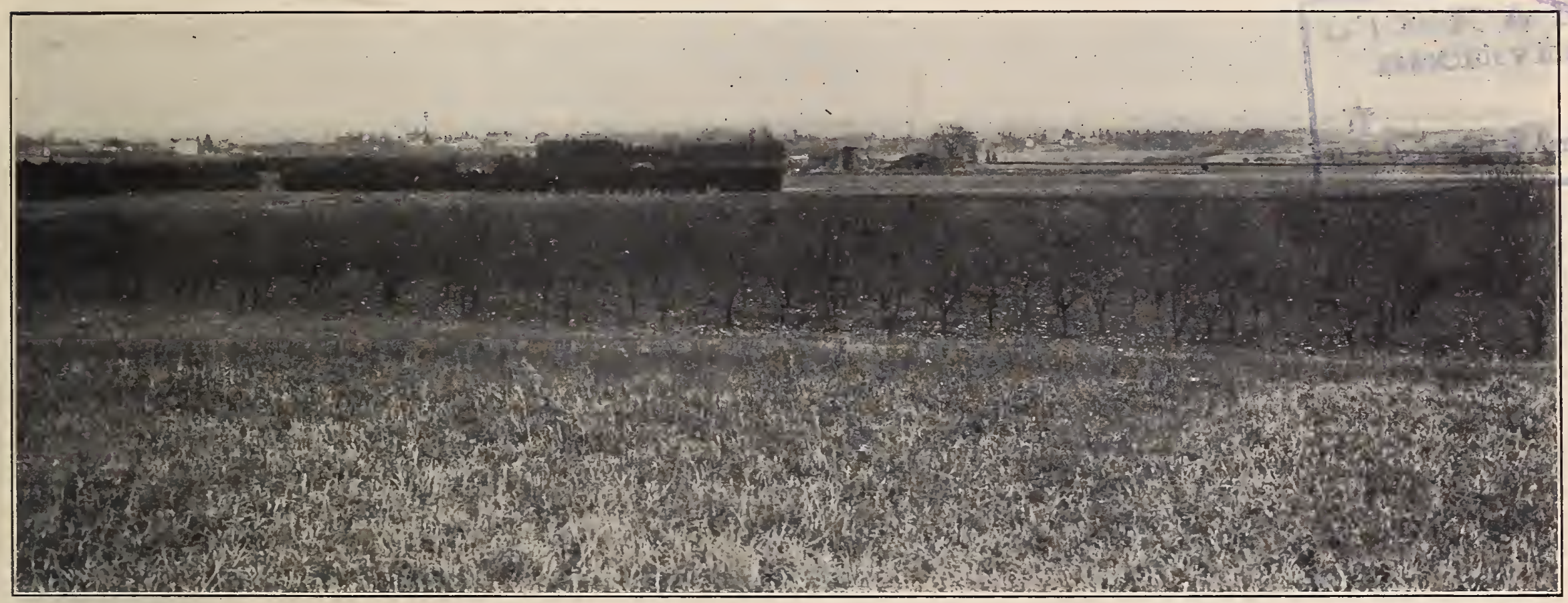

TWO ADJACENT FARMS.-The "Van Dusen Nurseries" Farm, and the "New York Agricultural Experiment Station"

This view is taken from the extreme western part of our farm, looking northeast over the Experiment Station grounds, the Station buildings being indicated by the high water tower a little to the left of the center. Seneca Lake and the city of Geneva, two miles distant, appear at the right.

The foreground shows a part of our famous Montmorency cherry orchard of five acres, whose record for the last five consecutive seasons is seventy-five tons of frujt-an average of fifteen tons per year. The large, low building with the open door near the center, is our packing barn with storage cellars beneath, where we have about a quarter of an acre of cellar room all under one roof. Our growing nursery stock lies mainly on the fat at the right, and beyond the hedge toward the Experiment Station. The large, white building at the left locates our trolley station about half a mile distant, at which point also we reach the Lehigh tracks.

WE GUARAITTE OUR VARIETIES. 


\section{FOREWORD}

Nurseries established 1839. Age in itself is of little value; a long established business, however, raises a presumption that it is one that is honestly conducted.

In 1839 the eminent pomologist, J. J. Thomas, started a small nursery business at Macedon, N. Y., later increased by plantings at Union Springs, N. Y., where for a large part of his life he made his home. In I 856 he sold a half interest to Edward W. Herendeen of Macedon, who three years later bought Mr. Thomas' entire interest. In $1867 \mathrm{Mr}$. Herendeen purchased the "Chelborg" farm, the present "Van Dusen Nurseries" farm, which lies just outside the present city limits of Geneva and adjoins the Experiment Station grounds. At this time he associated with him Mr. J. B. Jones of New York city, whose interest CURTIS L. VAN DUSEN, also of Macedon, purchased in I872. Mr. Van Dusen acquired the Herendeen interest a year or two later, and conducted a very successful business until his death in 1883 .

The present proprietor, a son-in-law of Mr. Van Dusen, entered the business in 1882 , and has now completed twentysix years of nursery experience.

About twenty years ago Mr. McKay added orcharding to his nursery interests, and since then has conducted the two branches of business together. During that period he has planted over twenty-three thousand apple, pear, plum, cherry, peach and quince trees, besides probably from forty to fifty thousand small fruit plants. Some of these plantings have of course been failures, but in the main, successful. His experience thus acquired qualifies hin to give valuable suggestions in regard to general orchard methods, varieties and location with reference to the matter of conmercial fruit growing, and particularly as to the very best assortments of fruit for the home garden. Any suggestions, or any information at his disposal will be gladly given by letter.
No. 99. STATE OF NEW YORK-DEPARTMENT OF AGRICULTURE.

Certificate of Inspection of Nursery Stock.

This is to Certify that the stock in the Nursery of the Van Dusen Nurseries, of Geneva, County of Ontario, State of New York, was duly examined in com pliance with the provisions of Section 83 of the Agricultural Law, and it wa found to be apvarently free from any contagious or infectious disease or diseases, or the San Jose scale or other dangerously injurious insect pest or pests.

$$
\text { C. A. WIETING, Commissioner of Agriculture. }
$$

\section{WHAT WE WILL DO.}

We guarantee varieties delivered by us to be true to name, and will make no substitutions except with the permission of the purchaser; if we are out of the size of trees ordered, we will substitute another grade of the same variety, unless requested not to do so, either charging or refunding the difference in price, as the case may be.

We will deliver at your railroad station, freight paid,'all orders amounting to ten dollars or more accompanied by cash; orders under ten dollars we deliver at station or express office, Geneva. We very strongly advise express shipment on all small orders, and with light packing on express shipments you will not find the difference in cost very material.

We will fill your order with trees and plants well rooted, free from disease, strictly first class for the variety and size ordered, and carefully packed and delivered in good condition.

We give you as reasonable prices as are consistent with the delivery of a high class of stock and a fair profit.

We will add to your order a rose bush, our selection of variety, free of cost.

WHAT WE WANT YOU TO DO.

If doubtful of our business reputation, look us up: Write the Geneva National Bank, the Importers and Traders' National Bank of New York City, or any citizen of Geneva.

REMEMBER-A ROSE BUSH COMES WITH EVERY ORDER-FREE. 
When you order, remit by post office or express money order, New York draft or registered letter. If you prefer stock to come by express C.O.D., send one-fourth of purchase price with the order. BE SURE TO

(I) state whether freight or express shipment is desired.

(2) give shipping point-town, county and state.

(3) if substitution is allowed, and to what extent.

(4) give post office address-office, county and state.

(5) sign name in full, and very plainly.

Авот'E ALL, we ask you to send your order early-now if possible, so as to avoid the rush and the likelihood of being sold out on many varieties, attendant on late orders.

\section{QUOTATION OF PRICES.}

In all quotations throughout this entire catalogue, it is intended that six or more take the dozen rate, twenty-five or more the hundred rate and two hundred and fifty or more the thousand rate.

Where smaller trees than the first two sizes are quoted, they are offered in order to give those who intend to plant on a commercial scale, good, thrifty, medium sized trees, specially adapted to the lower heading of trees which is now recognized as the best method in commercial orchards, and at a great saving in cost over the larger sizes. In this smaller size we do not care to accept orders of less than ten in any one variety as they will be already tied up in bundles of ten. For garden planting for family use, a higher headed tree is desirable, and for this purpose we advise one of the larger sizes.

\section{GENERAL CULTURAL DIRECTIONS, APPLYING TO ALL CLASSES OF FRUIT TREES.}

Planting-Trim roots severely before planting-this will hasten development of the root stysem; set the tree so that when it has fully settled the bud will be even with the surface or just below; the perfect way to plant the tree is to fill in with well fined soil till the roots are fully covered and the hole about $2 / 3$ filled, then fill with water without any tramping whatever, allow- ing the water to compact the soil about the roots : to do this properly the hole of course must be flooded; when the water has settled fill in the rest with dry fine soil which will act as a mulch. This way takes time but its results are perfect. If water is not used tramp the soil firmly about the roots leaving the top loose as before. Never tramp the surface.

Cultivation-The best opinion based on experience today, is for clean cultivation; even if it is intended to let the orchard run to sod finally, cultivation for the first few years is of great advantage.

Fertilizing - Never put fertilizer of any kind in the hole when planting-put it on top as top dressing. Nothing beats barnyard manure, but do not put it so close as to rest in any great quantity against the tree for a long time.

Mice injury - Protect by mounding up about ten inches high about the tree, by wrapping the trunk for the same height with tarred paper, or by using the "veneer" tree protectors. If the ground is perfectly free from litter no protection is usually required. In case of very deep snow, tramp it around each tree.

Trimming-When the tree is first planted, trim the head severely-cut out all but three for our branches entirely, and trim those back to three or four buds. If desired to make a head lower than the one grown in the nursery, in the lighter grades you can cut the stem off at the point where you want the new head. In the larger sizes, however, if this is done, some of them may fail to push buds freely from the heavy stem, although the majority probably would do so. EXCEPT WITH PEACHES, the modern experience goes to show that after this first trimming, if the tree is left alone except to give it the shape you desire and to cut out dead, broken and crossed limbs, it will have a tendency to bring the tree into bearing very much earlier. Excessive trimming stimulates wood growth at the expense of fruit buds. This is a subject, however, which each must decide for himself.

Diseases-Pests-Spraying, etc-Within the limits of this catalogue it will be impossible to go into this subject: We will, however, be very glad to give any information in our power on any of these subjects when requested, or to refer correspondents to the best authority on the subject.

DOES FRUIT GROWING PAY? SOMETIMES;

GLANCE THROUGH THESE FOOT NOTES. 


\section{FRUIT DEPARTMENT}

\section{APPLES.}

According to habit of growth and earliness of bearing, apple trees may profitably be set from 20 to 40 feet apart-we have planted Greening at $42 \mathrm{ft}$. filling in at $14 \mathrm{ft}$. throughout very profitably, with peaches. When set at the wider distances a "filler" of an early bearing variety of apple or of peaches or small fruits is always profitable, between the more widely planted apples.

Apples may be successfully grown on any good, well drained soil in this state, though there are of course certain localities where certain varieties do better than others. Bulletin 275 of the Experiment Station gives valuable information on "Apple Districts of New York with Varieties for Each.'

[The descriptions of all varieties of apples and crabs given here, slightly abbreviated, are taken from "Apples of New York" by Prof. S. A. Beach, former Horticulturist at the New York Experiment Station, now Professor of Horticulture at the Iowa State College of Agriculture, Ames, Iowa, to whom acknowledgment is very gratefully made. W. L. M.

\section{PRICES, except as noted.}

\begin{tabular}{|c|c|c|c|}
\hline a size, 5 to & $\begin{array}{l}\text { Each } \\
.25 \mathrm{C}\end{array}$ & $\begin{array}{r}\text { Per Doz. } \\
\$ 2.50\end{array}$ & $\begin{array}{l}\text { Per Hund. } \\
\mathrm{S}_{20.00}\end{array}$ \\
\hline lar size $4 \mathrm{~s} / 2$ to & $\ldots 2 \mathrm{OC}$ & 2.00 & I 5.00 \\
\hline ze $31 / 2$ & & I.25 & 10.00 \\
\hline
\end{tabular}

\section{EARLY VARIETIES.}

Early Harvest-Medium size; pale yellow, sometimes slightly blushed; flesh white, not firm, rather fine, crisp, tender juicy, subacid, good to very good. Late July and August.
*Red Astrachan-Medium size; pale yellow, often nearly or quite overspread with light and dark red, splashed and striped with deep carmine, with a heavy bluish bloom; flesh white often tinged with red, rather fine, crisp, tender, juicy, subacid, aromatic, good to very good. Late July to September.

Sweet Bough-Above medium to large; pale yellow, sometimes faintly blushed; flesh white, moderately firm, fine, somewhat crisp, very tender, juicy, sweet, aromatic, good to very good. August and early September.

*Yellow Transparent-Medium to above medium; pale waxy yellow, changing to an attractive, yellowish white; flesh white, moderately firm, fine grained, crisp, tender, juicy, subacid, pleasant but not high flavored, good. Late July and August.

\section{FALL VARIETIES.}

*Bismarck-Very large; greenish or yellow, striped with two shades of red, becoming solid dark red on the exposed cheek, with a thin bloom; flesh nearly white, moderately firm, coarse, rather tender, juicy, subacid, fair to good. October to early winter.

[NOTE-The tree is quite dwarfish in habit of growth; it is enormously productive and begins to bear within a year or two from planting. May safely be planted as close as 18 or $20 \mathrm{ft}$. Very hardy. W. L. M.]

*Duchess of Oldenburg-Medium to large; pale yellow, almost covered with splashes and stripes of bright red, mottled with crimson; flesh tinged with yellow, rather firm, moderately fine, crisp, tender, juicy, sub-acid, aromatic, good to very good for culinary purposes. Late August and September.

A SAFE MOTTO FOR THE COMMERCIAL GROWER-"FEW VARIETIES, MANY TREES." 
Fall Pippin-Large or very large; clear yellow, sometimes faintly blushed; flesh tinged with yellow, moderately firm, rather fine, tender, very juicy, agreeable sub-acid, aromatic, very good. Late September to January.

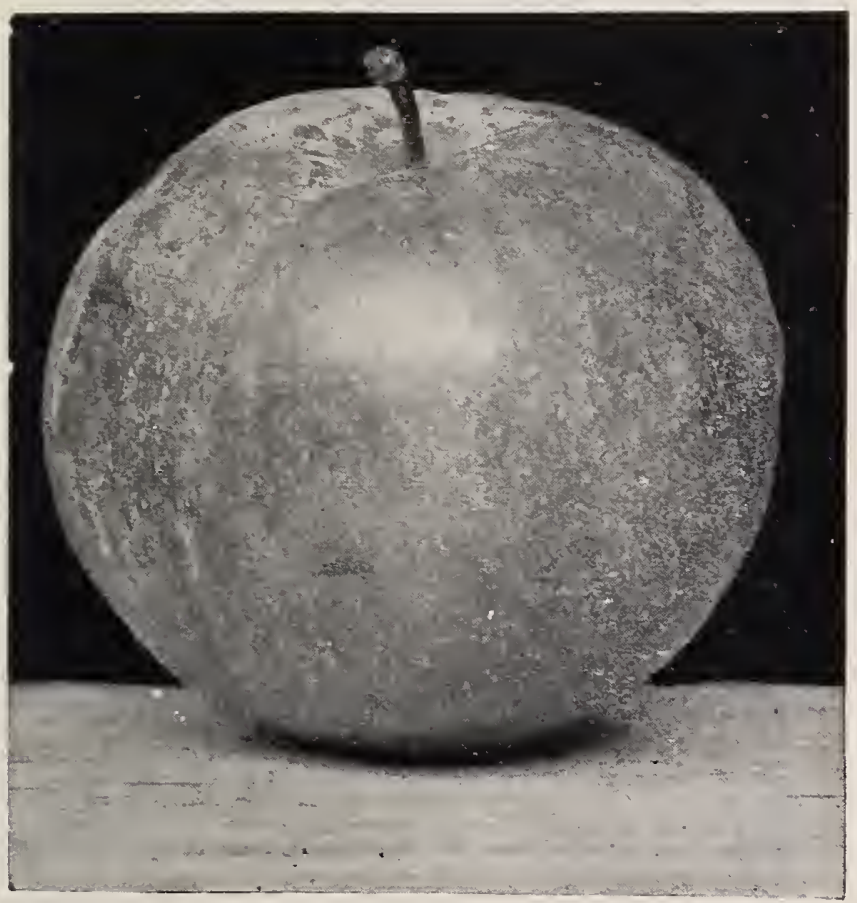

McIntosh RED-Highest quality of any variety.

*Fameuse - (Snow) - Average below medium; bright red, deepening to purplish black, somewhat striped toward the apex, flesh white, sometimes stained with red, very tender, juicy sub-acid becoming mild, aromatic, very good for dessert. October to mid-winter. [NOTE-There are variations' of this variety of inferior quality but stronger growers. The true Fameuse is a weak, crooked, miserable grower in the nursery, and we cannot deliver respectable looking trees. We advise the McIntosh instead of Fameuse - it's a better grower, the same type of apple, and better in quality, besides being a better keeper. W. L. M.]

King-Large to very large; yellow, mottled or washed with orange red, often shading to deep red, striped and splashed with carmine; flesh yellowish, rather coarse, crisp, tender, aromatic, juicy, sub-acid, very good to best. October to January. This variety probably ranks fourth in quantity grown in New York state.

*McIntosh-Above medium; clear whitish-yellow or greenish, washed and deeply blushed with bright red and striped with carmine, highly colored specimens becoming dark purplish red, overspread with a thin, lilac bloom: flesh white sometimes veined with red, firm, fine, crisp, tender, very juicy, agreeably aromatic, perfumed, sprightly sub-acid, becoming mild and nearly sweet when very ripe, very good to best for dessert. October to December or later. [Note-In our opinion this is the highest quality of any apple grown that we have ever eaten. It is rapidly pushing its way to the very front as a commercial variety. Fruit from our McIntosh orchard of 400 trees, partly in bearing, has always kept in common storage till after the holidays. This year we sold the last Jan. I 8th. Owing to scarcity of this variety we are obliged to make the price fifty percent higher on all quantities and all sizes. W. L. M.]

Maiden Blush-Medium to large; pale, waxen yellow with crimson blush; flesh white or with slight yellow tinge, fine, moderately crisp, tender, very juicy, sub-acid, good, especially for culinary uses. September to December.

Pound Sweet-(Pumpkin Sweet)-Large to very large; green, changing to yellow, marbled with greenish yellow, sometimes showing a brownish-red blush, but never a distinct red color; flesh tinged with yellow, firm, medium in texture, crispness and juciness, sweet, with a peculiar flavor; good for culinary use and especially for baking. October to January.

FOR THE HOME ORCHARD - "FEW TREES, MANY VARIETIES." 
Twenty Ounce-Very large; greenish, becoming yellow, washed, mottled and splashed with bright red, or deepening to dark red with carmine stripes; flesh whitish, somewhat tinged with yellow, coarse, moderately tender, juicy, sub-acid, good for culinary uses, second-rate for dessert. September to early winter.

*Wealthy-Above medium to large with a tendency to smaller size as trees age; pale yellow or greenish, blushed and marked with narrow stripes and splashes of red, deepening to brilliant red, very attractive; flesh whitish, sometimes stained with red, moderately fine, crisp, tender, very juicy, agreeable subacid, somewhat aromatic, good to very good. October to January.

*Wolf River-Large; bright yellow or greenish mottled and blushed with bright deep red and marked with conspicuous splashes and broad stripes of bright carmine; flesh tinged with yellow, firm, moderately coarse, tender, juicy, a little aromatic, fair to good. September to December.

\section{WINTER VARIETIES.}

Bailey Sweet-Above medium; bright yellow largely covered with deep red, mottled or striped with darker red; flesh tinged with yellow, firm, moderately coarse, moderately crisp, 'rather tender, juicy, decidedly sweet, agreeable in flavor, very good in quality. October to January or later.

Baldwin-Sometimes large to very large; skin light yellow, blushed or mottled with bright red, striped with carmine; flesh yellowish, firm, moderately coarse, crisp, rather tender, juicy, agreeable sub-acid, somewhat aromatic, good to very good. November to Narch or April. This is the leading variety commercially in New York, New England, Southern Canada, Michigan and Ohio. More Baldwins are produced in New York state than all other varieties put together. Further comment on its value as a commercial variety is unnecessary.

*Baxter-Large to very large; pale yellow mottled and blushed with bright red to purplish red, with a bluish bloom; flesh yellowish, firm, rather coarse, tender, moderately juicy, mild sub-acid, aromatic, fair to good. November to January.
Ben Davis-Aboxe medium to large; clear yellow or greenish, mottled and washed with bright red, striped and splashed with clear, dark carmine; flesh whitish, tinged with yellow, firm, moderately coarse, not very crisp, somewhat aromatic, juicy, mildly sub-acid, good. January to June. [КотеA very sure cropper and great keeper, and very handsome, though of inferior quality as grown in this state. W. L. M.]

*Boiken-Above medium to very large; waxy, bright yellow, often with pinkish-red blush; flesh white, firm, crisp, tender, fine grained, very juicy, sub-acid, good. November to March. [Note-This is a new variety of great promise, and is beginning to be grown commercially. Is very hardy, and in regions too cold for the $R$. I. Greening, it fills its place very acceptably as a first class winter, cooking apple. W. L. M.]

English Russet-Medium to small; pale green to yellow, more or less russeted, sometimes covered with clear golden russet, with no shading of red; flesh yellowish-white, firm, rather crisp, moderately tender, fine grained, not very juicy, aromatic, mild subacid, good. January to May.

Golden Russet-About medium; usually almost entirely covered with green or yellowish russet, in highly colored specimens becoming golden russet with bronze cheek; flesh yellowish, rather fine, moderately crisp, tender, juicy, rich, agreeably sub-acid, aromatic, very good; December to April or later.

Grimes' Golden-Nedium to large; clear deep yellow, with pale yellow or russet dots; flesh yellow, very firm, tender, crisp, moderately coarse, moderately juicy, sub-acid, rich, aromatic, very good to best. November to January.

Hubbardston-Above medium to large; yellow or greenish, blushed and mottled with red, varying from dull brownish to clear bright red; flesh whitish tinged with yellow, rather fine, tender, juicy, sub-acid, becoming mild, very good to best. January to April or later.

*Longfield-Usually below medium; pale waxen yellow with a pinkish blush, but not striped; flesh nearly white, fine, crisp, very tender, juicy, sub-acid, aromatic, good to very good. At Geneva is a fall apple, but further north may be kept through the winter.

\section{CHEMICAL PRICES ON LAST PAGES-FUNGICIDES, INSECTICIDES AND FERTILIZERS.}


Mann-Medium to large; deep green partly overspread with a brownish red blush, changing to a pronounced yellow color later in the season; flesh yellowish, moderately coarse, moderately juicy, hard, becoming later moderately tender and somewhat crisp, sub-acid, fair to good. MIarch or April.

Missing Link-Large; vellow, thinly mottled and striped with red on the exposed cheek; flesh rellowish, firm, coarse, tough yet somewhat crisp, moderately juicy, mildly sub-acid but eventually becoming sweet, fair in quality. A very late keeper.

Northern Spy-Large to very large; the clear pale vellow ground color is nearly concealed with bright pinkish-red, mottled and splashed with carmine and overspread with a delicate bloom; flesh yellowish, rather firm, moderately fine grained, very tender, crisp, very juicy, aromatic, sub-acid, very good to best. November to nearly the close of the season. This variety ranks third in the state in the quantity produced.

*Ontario-Large to very large; pale yellow washed with brownish red, striped with bright carmine; flesh whitish, tinged with yellow, rather firm, a little coarse, crisp, tender, very juicy, brisk sub-acid, aromatic, good to very good. Desirable for culinary use. This is a cross between two very high quality apples, Wagener and Spy, and is a fine variety. November to April.

Opalescent-Large to very large; skin glossy, taking a brilliant polish; pale yellow overspread with deep red, with scarcely perceptible streaks of purplish carmine; flesh distinctly tinged with yellow, rather firm, moderately tender, a little coarse, juicy, agreeable sub-acid, aromatic, good to very good. November to March. [Nоте-This is a variety of quite recent introduction; we have had it fruiting from grafts for three or four seasons, and we can recommend it as being valuable in a collection of varieties for home use. It has not been sufficiently tested to speak at all as to its possible commercial value. W. L. M.]
*Pewaukee-Above medium to large; green becoming yellow, washed or mottled with orange-red or red, striped and splashed with carmine, often covered with bloom; flesh nearly white, moderately firm, slightly coarse, rather tender, very juicy, sub-acid, slightly aromatic, fair to good. Xovember to April.

Rambo-Medium to large; pale greenish yellow, mottled with red, striped with carmine and overspread with grayish bloom; flesh whitish with tinge of yellow or green, firm, rather fine, very crisp, tender, juicy, mild sub-acid, aromatic, good to very good. Particularly desirable for dessert. Season very variable according to locality-generally November to March.

Rhode Island Greening-Above medium to large; green varying to yellow, sometimes with brownish red blush, which rarely deepens to a bright red; flesh yellowish, firm, moderately fine grained, crisp, tender, juicy, rich, sprightly sub-acid, peculiarly flavored, very good in quality. October to March or April. [Note-This apple ranks next to Baldwin in amount produced in the state, the best estimates crediting to Baldwin and Greening together over two thirds of the commercial apple crop of New York. Notwithstanding the general preference of the market for red apples, the report today quoting "fancy Baldwins, Seeks, Spitz and Spys at $\$_{2.7 .5}$ to $\$_{3.50}$ " quotes "Fancy Greening at $\$_{3} .50$ to $\$_{4} .00 . "$ This is generally about the way Greening prices compare with these other varieties from January on. It is a great cropper and with just ordinary good care will outyield any other of the standard varieties in the quantity of No. I fruit it will give. It stands best of all varieties as a cooking apple, and as a dessert apple it also ranks very high. This is one of the three varieties we are now planting on the old "Van Dusen" farm, the other two being Baldwin and McIntosh. W. L. M.]

Roxbury Russet-Above medium, variable in shape; skin somewhat tough, usually covered with greenish to yellowishbrown russet: flesh tinged with yellow or greenish, firm, somewhat coarse, moderately tender, juicy, sub-acid, good to very good. December to May.

\section{MAY WE SEND YOU I 2 "MCKAY'S LATE" PEACH TREES? SEE OUR OFFER PAGE I8.}


Seek-no-Further-Above medium; deep yellow or greenish shaded and splashed with rather dull red, in highly colored specimens overspread with bright, pinkish red, striped with deep carmine; flesh tinged with yellow, firm, a little coarse, crisp, tender, juicy, mild sub-acid, rich, aromatic, very good to best. November to February.

Senator-Below medium to large; deep rich yellow often almost covered with bright red, striped with darker red, in the sun deepening to a very dark blush; flesh tinged with yellow, firm, moderately fine, crisp, rather tender, juicy, aromatic, sprightly sub-acid, very good to best. November to February.

Stark-Medium to large; pale green becoming yellow, more or less blushed or mottled with red, and rather indistinctly striped with darker red; flesh yellowish, firm, somewhat coarse, rather tender, juicy, mild subacid, fairly good. January to May or June. [Note-A variety worthy of commercial planting; it has a long list of excellent pointstree an extra strong grower-hardy-very prolific- reliable annual cropper-attractive-good shipper -splendid keeper, and does well in all regions where the Baldwin succeeds. W. L. M.]

Stayman's Winesap-Medium to large; green becoming yellowish, often nearly completely covered with rather dull mixed red indistinctly striped with dull carmine; flesh tinged with yellow or greenish, firm, moderately fine grained, tender, moderately crisp, very juicy, aromatic, pleasant sub-acid, good to very good. December to May.

Sutton's Beauty-Medium size; attractive bright red striped with carmine, nearly overspreading the lively yellow or greenish ground color; flesh tinged with yellow, rather firm, moderately fine grained. crisp, tender, juicy, mild sub-acid, good to very good. November to March.

*Talman Sweet-Below medium; skin tough, marked with suture lines sometimes extending almost from the cavity to the basin; pale clear yellow, sometimes a little blushed; flesh white, firm, neither tender nor crisp, rather hard, moderately fine, somewhat juicy, sweet, good to very good. November to January.

Wagener-Medium to large; -skin glossy, bright pinkish red striped with bright carmine; flesh whitish, tinged with yellow, moderately firm, rather fine grained, crisp, tender, very juicy, sub-acid, aromatic, very good to best. November to February. [NoTE-While a good grower in the nursery it is a very poor one in the orchard, and as a good producer is short lived; bears early with tendency to overbear; in localities where it does well it is an excellent variety to plant as fillers among other varieties of apples. Its quality is very high. W. L. M.]

Walbridge-Below medium; green becoming pale yellow washed with red, mottled and striped with bright carmine, overspread with thin bloom; flesh whitish tinged with yellow, firm, a little coarse, crisp, moderately tender, juicy, mild sub-acid, slightly aromatic, fair to good. November to March.

Winter Banana-Large to very large; waxy pale yellow, with pinkish red blush; flesh whitish, tinged with yellow, moderately firm, a little coarse, somewhat crisp, tender, juicy, mild sub-acid, aromatic, good to very good. November to April.

Yellow. Bellflower-Size variable, small to very large; bright lemon yellow, varying to whitish in the shade, often with a shade of brownish red in the sun; flesh whitish, tinged with pale yellow, firm, crisp, moderately fine grained, rather tender, juicy, aromatic, good for culinary use, acid, becoming sub-acid later. December to April.

York Imperial-Medium to large; yellow, blushed with red and indistinctly streaked with carmine; flesh yellowish, firm, crisp, a little coarse, moderately tender, moderately juicy, mild sub-acid, becoming nearly sweet, aromatic, good to very good. Here, January to April.

\section{DO YOU SPRAY? OUR COPPER SULPHATE AND ARSENATE OF LEAD PRICES WILL SURPRISE YOU.}




\section{CRAB APPLES.}

Same price as apples.

*Exceisior-Nearly as large as a medium sized apple; yellow shaded and splashed with red over much of its surface; flesh whitish, firm, a little coarse, crisp, juicy, sub-acid, agreeable for dessert use, good to very good. Early September.

*Hyslop-Medium to large; pale yellow almost completely overspread with dark red to purplish carmine, with thick, blue bloom; flesh yellow, very firm, fine, juicy becoming dry later, sub-acid, astringent. Late September and October.

* Martha-Unusually large; clear pale yellow almost entirely covered with bright red, with purplish bloom; flesh yellowish moderately coarse, crisp, juicy, sub-acid, good to very good. September to November.

*Transcendent-Medium to large; bright yellow with bright red cheek, overspread with bloom, sometimes nearly covered with red; flesh yellow, crisp, juicy, moderately fine, somewhat astringent, sub-acid, very good for culinary use. Late August to middle of September.

Fireside Collection-hardy varieties only. One each of the following varieties, extra size, $\$ \mathrm{r} .25$, regular size $75 \mathrm{C}$. Yellow Transparent Duchess Talman Sweet McIntosh Boiken Wealthy.

Family Collection-Choicest varieties for general family use One each of the following varieties, extra size $\$_{1.25}$, regular size $75 \mathrm{c}$.

$\begin{array}{lll}\text { Bailey Sweet } & \text { McIntosh } & \text { Greening } \\ \text { Yellow Transparent Russet } & \text { Spitzenburg. }\end{array}$

For commercial planting the following varieties are perhaps most worthy of general recommendation, always bearing in mind to avoid varieties which the experience of others has shown not to be adapted to your locality: Duchess, Fameuse, King, McIntosh, Wealthy, Baldwin, Ben Davis, Boiken, Hubbardston, Longfield, Northern Spy, R. I. Greening, Russet, Spitzenburg, Stark.

* In Bulletin No. 275 from the Experiment Station recommended or considered worthy of trial in the severe climate of the extreme northern part of the state. Among the very hardiest are Duchess, Wealthy and McIntosh.

\section{SPECIAL PRICES ON TREES FOR TOPGRAFTING .}

To those planters who prefer to plant good strong, hardy varieties and then top graft them from certain bearing trees so as to get just that strain of fruit, we will quote especially attractive prices in quantity, having in view the selection of sorts for which we may not have so much demand.

\section{STANDARD PEARS}

\begin{tabular}{|c|c|c|c|}
\hline Extra size, $5^{-7} \mathrm{ft} \ldots$. & $\begin{array}{l}\text { Each } \\
35 \mathrm{C}\end{array}$ & $\begin{array}{l}\text { Per Doz. } \\
\$_{3} 50\end{array}$ & $\begin{array}{l}\text { Per Hund. } \\
\$ 2500\end{array}$ \\
\hline Regular size $4-6 \mathrm{ft} \ldots$ & $25 \mathrm{C}$ & 250 & 2000 \\
\hline Medium size $3-4 \mathrm{ft} \ldots \ldots \ldots \ldots$ & & 200 & I 500 \\
\hline
\end{tabular}

Pears require a strong soil for the best development of tree and fruit A rich loam topsoil with strong clay subsoil is for the great majority of varieties the ideal soil. Of course the land must not be wet.

Never plant closer than $16 \mathrm{ft}$. in commercial orchards, and i 8 or more is better; one of the very highest authorities as a pear grower says " $20 \mathrm{ft}$. for Bartlett, $22 \mathrm{ft}$. for Seckel." In garden or lawn of course much closer planting is allowable.

\section{EARLY VARIETIES.}

Bartiett-Stands in the same relation commercially among ot her pears, as Baldwin does among apples. Large size; rich yellow when ripe, with a beautiful blush cheek; highly flavored, juicy, buttery, very vigorous, bears very abundantly at a comparatively early age, and is an annual bearer. August and September. Price, add $50 \%$ to above list, on all quantities and sizes. [Note-The Bartlett is preferred by the canners to any other variety, so that no matter how large the crop, Bartlett always sells at a fair price at least, even when other varieties go begging. The crop of Bartlett from the Van Dusen orchards the last season sold for $3 \frac{1}{2} \mathrm{c}$ per pound for firsts and seconds together, delivered in crates to the canners. There is no other variety that is safer today to plant on a commercial scale than Bartlett pears. W. L. M.]

Clapp's Favorite - Very large; yellow marbled with red; very high, rich quality. Should be gathered very early. August.

OUR BARTLETTS THIS YEAR BROUGHT OVER \$200.00 
Lincoln Coreless-Large; when ripe a rich golden yellow; flesh yellow, very good, rich and juicy; when picked green and laid away to ripen it will keep for several months. Its two distinct characteristics are its very late keeping qualities, and the entire absence of core.

Seckel-Small; greenish russet with rich crimson cheek; acknowledged by fruit growers generally to be the highest in quality as a dessert pear of any variety grown. A very heavy, annual cropper, tree very hardy and vigorous. October to December. [NotE-This variety we have recently begun to plant commercially; from the experience of ourselves and others we believe that this variety added to Kieffer and Bartlett, will make the best trio of commercial varieties that can be selected. While the tree in the orchard is a strong and vigorous grower, in the nursery, though vigorous, it is a very short grower as will appear from a comparison of Seckel and Bartlett in the cut, both varieties being of the same age and same diameter tree. In all grades quoted, the Seckel will run ten to twelve inches below sizes mentioned in list. W. L. M.]

Sheldon-Very large, round, apple shape; when first picked an even greenish russet all over, changing to a rich golden russet when ready for use. In quality is with the very best as an eating pear, though it is so tender and soft that it is of little value commercially. October and November. [NoteThis variety originated probably fifty or more years ago on the lot in city of Geneva where the proprietor of the Van Dusen Nurseries has made his home for over 25 years. W. L. M.]

Vermont Beauty-Medium size; a beautiful seedling from Vermont, roundish, nearly covered with rich carmine; a very hardy, productive and vigorous variety. October and Nov.

Worden-Seckel-Medium size, clustered, a seedling of Seckel; juicy, buttery, fine grained, with a flavor and aroma approaching in excellence its parent, which it surpases in size, beauty and keeping qualities. October to December. This is a new variety and is also a very light, slender, poor grower in the nursery; owing to these two facts we are obliged to make its price double for all sizes and numbers quoted in list.

ARSENATE OF LEAD CANNOT HURT FOLIAGE.

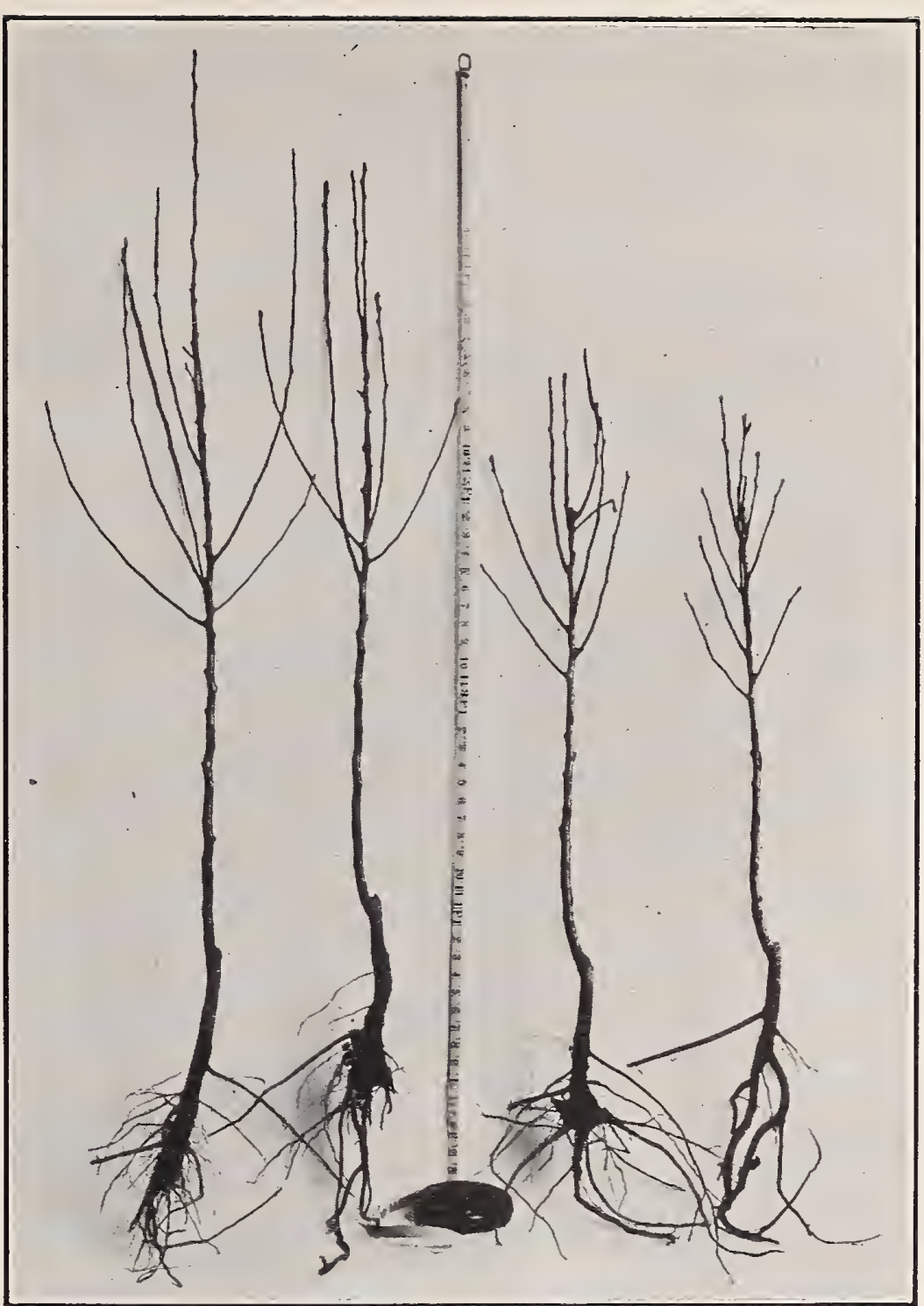

2 YeAR BARTLETT 2 YEAR SECKEL Regular and Medium size; showing difference in habit of growth Both are same age and same caliper 
Home Collection of Pears-A desirable collection for home use, from earliest to latest. I each extra size, \$I.50;. regular size, \$1.00.
Clapp's Favorite
Bartlett
Flemish Beauty
Kieffer
Duchess
Lawrence.

\section{SPECIAL TO COMMERCIAL PLANTERS.}

We have a two year old block of very thrifty, somewhat lowheaded pear trees, which we are anxious to clear off the coming spring. The four trees shown in the cut are taken from this block, the two at the left being Bartlett and the others Seckel. In this block are also Kieffer and Clapp's, these two varieties running at least as strong as the Bartlett. In order to clear this block we will offer them at the following rates in lots of roo or more for orders received within the next two weeks, or until they are sold out.

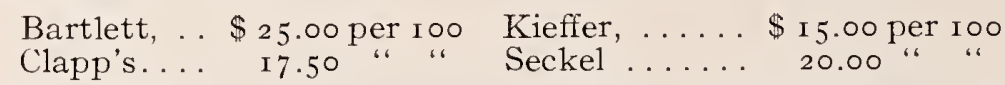

From the same block, the same varieties in a little lighter tree at $\$ 5.00$ per 100 less.

\section{DWARF PEARS.}

May be set much closer than standards, but would not advise closer than $\mathrm{I} 4 \mathrm{ft}$. They are adapted mainly to garden planting, not comparing with standards in most sections for commercial planting.

Set dwarf pear trees so that when fully settled the bud will be about four inches beneath the surface.

$$
\begin{aligned}
& \text { Extra size, } 3-4 \mathrm{ft} \ldots \ldots \ldots \ldots \ldots \text { Each } \quad \ldots \ldots \text { Per Doz. Per Hund }
\end{aligned}
$$

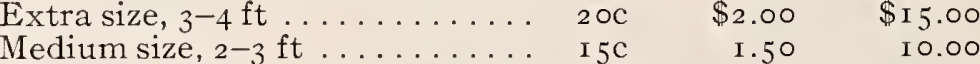

$$
\begin{aligned}
& \text { Bartlett, Clapp's, Duchess and Seckel are most highly }
\end{aligned}
$$
recommended.

\section{CHERRIES.}

A rather loose, dry, gravelly soil is best for cherries, although it is a fruit that seems generally over the state, to do "pretty well," no matter what its location, only so the soil is dry.

After the trimming when planted, the cherry is a tree that should not be further touched with the knife, except to give it shape, and to cut out broken, dead or crossed limbs.

There is such similarity between many of the different varieties of cherries that we shall describe only five varieties which by our own and many others' experience, have proved the very best types for both home and commercial growing. All cherry trees, and the sweets in particular, are very scarce this year, and we advise purchase of the smaller sizes, especially as they are rapid growers after becoming established.

\section{SWEET VARIETIES.}

Plant 20 to $22 \mathrm{ft}$. apart.

$\begin{array}{llrr}\text { Extra size, } 5-7 \mathrm{ft} \ldots \ldots \ldots \ldots \ldots & \begin{array}{c}\text { Each } \\ 45 \mathrm{C}\end{array} & \begin{array}{r}\text { Per Doz. } \\ \$ 4.5^{\circ}\end{array} & \text { Per Hund. } \\ \text { Regular size, } 4-6 \mathrm{ft} \ldots \ldots \ldots \ldots & 35 \mathrm{C} & 3.50 & \\ \text { Medium size, } 3-4 \mathrm{ft} \ldots \ldots \ldots \ldots & & 2.5^{\circ} & \$ 20.00\end{array}$

Napoleon Bigarreau-Very large; pale whitish yellow, almost covered with a rich, brilliant carmine when fully ripe; flesh yellowish, extremely firm, sweet and rich. Very vigorous and a heavy annual bearer. This is the variety canners use in preference to all other sweet varieties when they can get it. We have fruited this variety commercially several years, and found it very profitable. July first to tenth.

Windsor-Without doubt the best black cherry grown, both for home and commercial purposes. Is large, very firm, rich and meaty, a good shipper and very attractive. About a week later than Napoleon.

Other best sweet varieties-Black; Black Tartarian, Schmidt's Bigarreau. Light Colored; Gov. Wood, Rockport, Yellow Spanish.

OUR MONTMORENCY RECORD, 1903 to I907, INCLUSIVE: 5 ACRES, : 
SOUR VARIETIES.-Plant i 6 to i $8 \mathrm{ft}$. apart.

All sour varieties are lighter growers than the sweets, and are graded correspondingly shorter.

$\begin{array}{llrr}\text { Extra size } 4-6 \mathrm{ft} \ldots \ldots \ldots \ldots \ldots & \text { Each. } & \begin{array}{r}\text { Per Doz. } \\ S_{3.25}\end{array} & \begin{array}{r}\text { Per Hund. } \\ \mathrm{S}_{25.00}\end{array} \\ \text { Regular size, } 3-5 \mathrm{ft} \ldots \ldots \ldots \ldots & 25 \mathrm{c} & 2.75 & 20.00 \\ \text { Medium size, } 2 \mathrm{t} / 2-4 \mathrm{ft} \ldots \ldots \ldots \ldots & & 2.00 & 15.00\end{array}$

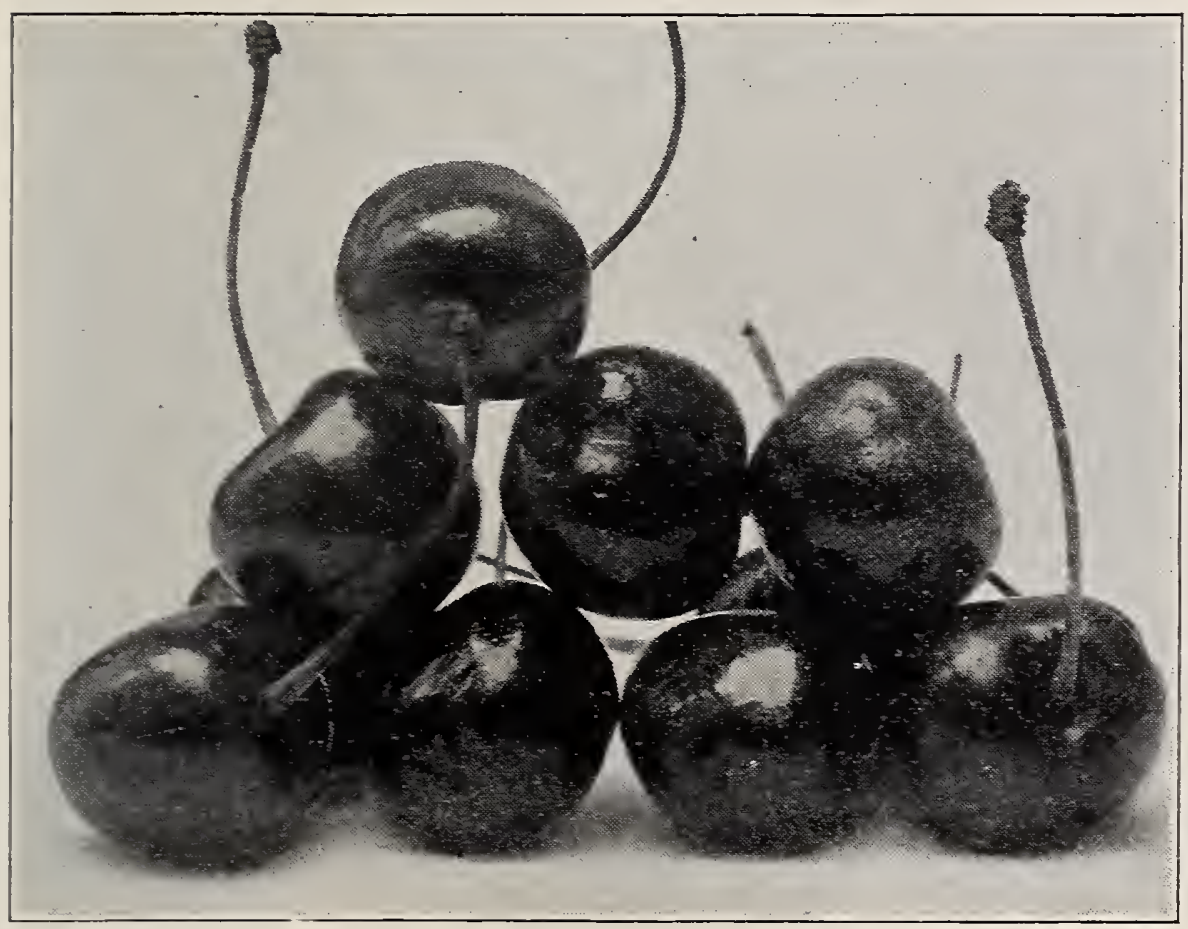

Large MoNTMORENCY
Early Richmond-Medium size; dark red, very juicr, quite acid; its commercial value is from its earliness which brings it intomarket early enough to realize the top prices. Do not plant it for canning purposes. Last few days in June and first few days in July.

Large Montmorency-As compared with Richmond, larger, less acid, brighter red, ten to twelve days later, less juicy, firmer, more meaty, making it an ideal variety for canning. The range of seasons with us for the last few years has been, earliest July 4, latest July 26 , with small pickings possible both before and after those dates. [ХотE-If you are within reach of the canning industry as an outlet, you are safe to plant very heavily on this variety. If you have a good home market, plant stronger than Richmond; if depending on shipping on commission to the city markets we advise planting stronger on Richmond. In planting this variety be sure and get the Large Montmorency, and not the Montmorency Ordinaire. Our trees are the former, budded from our bearing trees. W.L. II.

English Morello- Very dark red, almost or quite black when ripe, when they attain very large size. Very acid, very rich, very juicy. When people refer to the "old fashioned sour cherry," this is the variety they have in mind. Trees very light growers, dwarfish, but heary and annual bearers. Can be planted much closer than Richmond or Montmorency, comparatively short lived. In great demand commercially owing to the value of their juice in the manufacture of extracts; their price in quantity has gradually risen to equal the Montmorency. Last of July.

Other best sour varieties-Baldwin, (new) Empress Eugenie, Late Duke, Louis Phillippe, May Duke, Olivet, Ostheim.

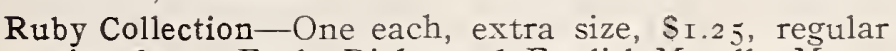
size, S r .00. Early Richmond, English Morello, Montmorency, Napoleon, Windsor.

5 CONSECUTIVE YEARS, \$260,00 PER ACRE PER YEAR, AND A CROP IN SIGHT FOR Ioo8. 


\section{PLUMS.}

Plant I 6 to 18 feet apart each way. The plum is a heavy feeder, and requires a good rich soil, and will stand plenty of fertilizing. It does best on our rich deep loams, with clay sub-soil.

\section{JAPAN VARIETIES.}

$\begin{array}{lccr} & \text { Each } & \text { Per Doz. } & \text { Per Hund. } \\ \text { Extra size, } 5-7 \mathrm{ft} \ldots & 25 \mathrm{c} & \$ 2.50 & \$ 20.00 \\ \text { Regular size, } 4-6 \mathrm{ft} . & 20 \mathrm{c} & 2.00 & 15.00 \\ \text { Medium size, } 3-5 \mathrm{ft} . & & 1.50 & 10.00\end{array}$

The Japan varieties are very distinct from the European varieties in their very early bearing proclivities, in being heavier bearers with more highly colored fruit running mostly to strong reds, and the exceedingly strong character of growth. They are tremendous growers, and tremendous croppers. They are as a whole rather inferior to the European varieties in quality, but on the other hand they grow in many localities where the others will not, and so fill a decidedly useful place.

Abundance-Average large size, bright cherry red, flesh yellow, juicy, good, last of July.

Burbank-Large; darker red than Abundance, splashed and streaked over a rich golden yellow ground; flesh yellow, sweet and rich. The leading Japan commercial variety. August.

Red June-Medium to large; a rich purplish red, very handsome; flesh yellow and very good. The earliest ripening of all the plums, and profitable or that reason as a commercial variety for a limited quantity.

October Purple - Large size, rich purple color, flesh a little coarse but very good. A very late variety.

Satsuma-Large; both skin and flesh of the same dark, purplish red color; small pit, juicy, rather better quality than most Japans; a good canning variety. September.

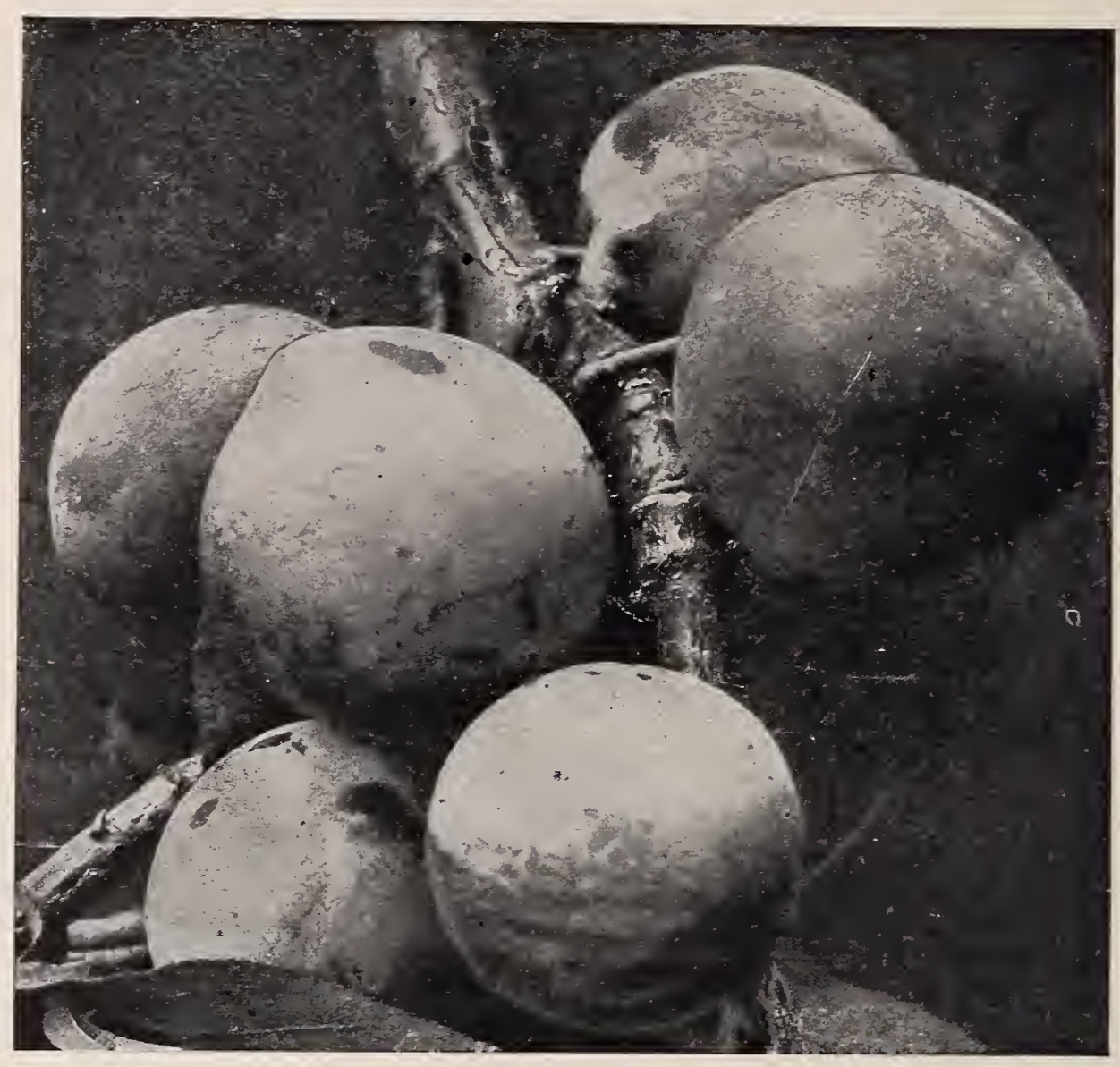

BURBANK-Most profitable Japan variety

NOTICE THE LOMBARD PLUM - IT DOES BUSINESS THE “OFF YEARS," AND PAYS. 
Wickson - Extremely large-probably the largest of any variety either of the Japans or Europeans. From time it is half grown till nearly ripe it is of a soft, ivory white color, when pink shadings begin to appear, deepening to a rich, glowing carmine, with a heavy bloom, with a decidedly purple cheek when fully ripe. It is perhaps the handsomest plum of any in our list. Tree entirely different in habit from other plums, more resembling an apricot tree. Is not so heavy a bearer as other Japans, but keeps well if picked fairly early, and may be shipped quite green and ripen in the basket. About September first.

Mikado Collection-One each of above six varieties extra size, $\$$ I.oo regular size, $75^{\mathrm{c}}$.

\section{EUROPEAN VARIETIES.}

Each Per Doz. Per Hund. Extra size, $4 \mathrm{~T} / 2-6 \mathrm{ft} \ldots \ldots \ldots \ldots \ldots{ }_{25 \mathrm{C}}$ Regular size, $33^{\mathrm{I} / 2}-5 \mathrm{ft} \ldots \ldots \ldots .20 \mathrm{c}$

$\begin{array}{ll}\$ 2.50 & \$ 20.00\end{array}$ $\begin{array}{lll}20 \mathrm{C} & 2.00 \quad \mathrm{I} & \mathrm{5} .00\end{array}$ Medium size, $3^{-4} \mathrm{ft} \ldots \ldots \ldots \ldots . .1 .50 \quad$ I .00

Arch Duke - New; a very large, purple plum, ripening about October first. Is proving to be a valuable variety.

Bradshaw-Very large, egg shaped ; dark violet red changing to purple when ripe; flesh yellow, rather coarse, sweet, rich, juicy, very fine quality, and one of the best if not the best dessert plum, but not valuable as a market variety except for short distances. August fifteenth.

German Prune-A large, oval purple plum, freestone, a splendid shipper, commands the top price and is a very profitabie variety. It makes a very fine plum for canning unless one prefers a light colored one. September.

Grand Duke-Good size; very dark, short necked; flesh yellow, rich and sweet. Becoming popular as a market variety September.

Lombard-Medium size, oval, violet red, freestone: not a high price variety usually, but it bears tremendous crops almost yearly, and often when other plums are not producing, when it becomes very profitable. August middle to last. [NoTEFor the average grower and the average season we regard
Lombard as next to Reine Claude as a profitable commercial variety. W. L. M.]

Monarch-A new, large sized plum, running very even in size on the tree, round, and very handsome, with a beautiful bloom; its quite late season makes it a valuable acquisition.

Reine Claude-The true Green Gage-Large, round, green turning to the most perfect golden yellow when ripe, in which stage it compares with Bradshaw as a dessert plum of the very highest quality. Flesh throughout its changes is the same as the skin in color; freestone. September, October. [NoteThis variety is more in demand by the canners than all other varieties put together. In the past twenty years a third of all our plums have been Reine Claude, and they have produced double the money that the other two thirds have. We cannot help ranking this above all other varieties for profit. The trees are short lived, and to grow Reine Claude one should plant an orchard about every ten years. W. L. M.]

Shropshire Damson-An improved Damson. Takes the place of the old Damson variety, is a little larger, more productive and always in demand in the markets. September.

Yellow Egg-Very large, egg shaped; a beautiful, golden yellow; coarse, but a good cooking variety. Rots very readily. Last of August.

Seneca Valley Collection-One of each of the following six varieties, selected for their adaptation for home use. Extra size, \$1.00. Regular size, $75 \mathrm{c}$.

Bradshaw German Prune Lombard

Reine Claude Shropshire Damson Yellow Egg

\section{APRICOTS.}

Extra size, $4 \mathrm{I} / 2-6 \mathrm{ft} \ldots \ldots \ldots \ldots . \quad \begin{array}{ccc}\text { Each. } & \text { Per doz. } & \text { Per } 100 . \\ \$ 2 & \$ 2.50 & \$ 20.00\end{array}$ Regular size, $3-4 \mathrm{t} / 2 \mathrm{ft} \ldots \ldots \ldots .20 \mathrm{C} \quad 2.00 \quad$ I 5.00

Montgamet-A large, rich yellow apricot of the very finest quality. Owing to the comparatively limited demand for this fruit we confine ourselves to growing this one variety, knowing it to be the best of all.

OUR LAST REINE CLAUDE CROP BROUGHT \$275.00 PER ACRE DELIVERED IN CRATES. 


\section{QUINCES}

Quinces require a good rich soil, perhaps with a little more moisture than most other fruits.

Erch Per Doz. Per Hund.

Extra size, ${ }_{3}-4 \mathrm{ft} \ldots \ldots \ldots \ldots .30 \mathrm{c} \quad \$_{3.00} \mathrm{~S}_{25.00}$ Regular size, $2-3 \mathrm{ft} \ldots \ldots \ldots \ldots{ }_{25} \mathrm{C} \quad 2.50 \quad 20.00$

Bourgeat-A new variety, very highly recommended. Large size, smooth, rich golden color, a late keeper. The most vigorous grower of all varieties.

Champion-A strong grower, very early bearer, about two weeks later than Orange. Small, two year trees right in the nursery row are very often loaded with fruit.

Orange-Large, round, golden yellow. The standard commercial variety everywhere.

\section{PEACHES}

The varieties offered in this list are all of our own growing. Realizing the great danger of mixtures in growing peach trees, no matter how careful or conscientious the grower may be, three years ago we procured buds from tested, bearing trees, budded a stock row from these buds, and have since used buds so procured. In addition to varieties taken from our own bearing trees, we make acknowledgment for tested buds to the following; Mr. B. J. Case of Sodus, N. Y., Chairman of the Executive Committee of the N. Y. State Fruit Growers' Association; to Mr. S. D Willard, of Genera, Vice President for many years of the Western N. Y. Horticultural Society; to the State Experiment Station, and to Mr. G. F. Forden of Geneva. The reason for so many mixtures in varieties of peach trees is not necessarily in dishonesty of the nurseryman, but a mixture in peaches is much more difficult to detect than in the other classes of fruit trees in which the nurseryman can tell the various varieties by their appearance, and when such a mixture is once overlooked and buds taken from the intermixed varieties, a very few seasons will lead to the most serious results. We are making the growing of peach trees a specialty, and shall continue to renew our buds from bearing trees as often as every three years so as to reduce to a minimum the likelihood of mixtures.
The peach requires a warm, loose gravelly or sandy loam soil, to give the best results, and above all else it must be well drained. Planted in orchard by itself I 6 to i 8 feet is recommended, but when planted as fillers they may be set closer if desired. Trees should be pruned each year, usually in late winter or early spring, removing from $1 / 2$ to $3 / 4$ of the preceding season's growth.

Each Per Doz. Per Hund.

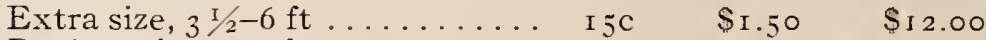
Regluar size, $3-4 \mathrm{ft} \ldots \ldots \ldots \ldots$ I OC $\quad$ I.00 8.00 Medium size, $2 \mathrm{~s} / 2-3 \mathrm{I} / 2 \mathrm{ft} \ldots \ldots \ldots . . . .50$

Alexander-Medium size; deep maroon on greenish yellow ground, shaded and splashed with carmine, clingstone. good quality, extremely early. Middle to last of July.

Belle of Georgia-A new, large, white variety, which is proving itself to be valuable in many localities. August.

Carmen-Large, resembling Elberta in shape; pale yellow over spread with a deep blush; flesh tender, very juicy, fine flavor. $A$ new variety which is rapidly gaining popularity August.

Chair's Choice A large, very late, yellow peach; good quality, a good shipper, and a very valuable market variety. October.

Champion-Very early and very good. Creamy white, with red cheek, freestone. First of August. The tree of this variety is a very strong grower, and the fact that it is so early and a perfect freestone makes it very desirable.

Crawford's Early-It seems unnecessary to describe this fine old variety. Its large size, fine rich yellow color with red cheek and the high quality of its rich yellow flesh, have made it the basis for a comparison in excellence of all varieties which conform more or less to its chief characteristics. The Crawford "type" of peach is so well recognized in the market, that those peaches which come later and are of this general type of peach, have succeeded best as commercial varieties. Two striking instances of this occur in the Willett and Lamont. First of September.

OUR PEACH TREES ARE GROWN FROM STOCK BUDDED FROM TESTED, BEARING TREES. 


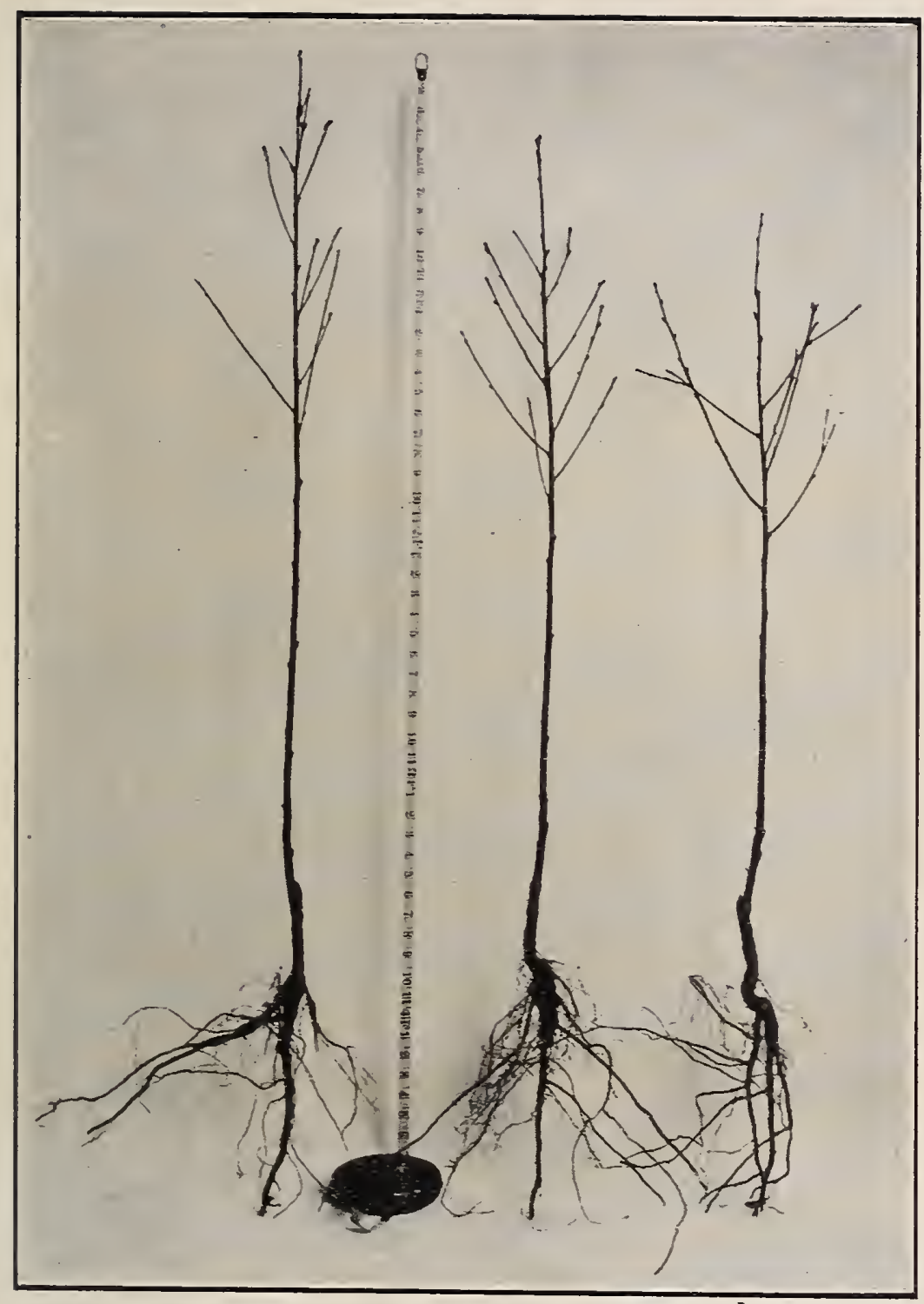

Crawford's Late-Large, yellow with red cheek; flesh yellow, quality high for so late a variety. Last of September.

Crosby-Medium size; yellow, splashed with crimson; flesh yellow, juicy, good quality. One of the very hardiest varieties. Middle of September.

Elberta-Large to very large; fruit somewhat elongated, flattish: flesh yellow, firm, not very juicy nor of high quality, but without doubt is the most popular market variety of today, on account of its great productiveness, uniformly large size, handsome appearance and remarkable shipping qualities. It follows immediately after Early Crawford.

Fitzgerald-A new, medium to large size, round peach, same season as Early Crawford, originating as a chance seedling in Canada. Yellowish green with a decided cheek, vellow flesh, and fine quality. It is hardy and very productive, and seems to have sprung into favor very rapidly-

Greensboro-Claimed to be the largest of the very early varieties. Fine color, rich white flesh, as early as Alexander and Freestone when fully ripe.

Hill's Chili-Medium size; dull yellow with more or less red cheek, skin very thick and tough with rery heavy down flesh yellow, not very juicy, exceedingly rich, very firm, stands handling and shipping well. Its quality when canned is of the rery highest, and where quality rather than extremely large size is wanted, the canners prefer it to all other varieties. Early October. [Note-Its extreme hardiness in the bud has giren us crops of this rariety when most other varieties have been winter-killed. In our opinion it is nearly or quite as hardy as Crosby. The tree is very long-lived. We have orer I 300 of this variety planted, partly in bearing, and for this region which is almost too cold to be called a peach region, it has proved very profitable. II. L. M.]

Kalamazoo-A large, fine, yellow variety, very largely grown in the peach belts of Michigan, and becoming more popular in the east. September.

WE ARE SPECIALISTS IN GROWING PEACH TREES. 
Lamont-A large, new peach, fast taking its place in the commercial list. The description of Early Crawford is a description of this variety, except that the Lamont is freer from injury in the bud, from specking in the fruit, and in every way more resistant to similar faults. Its heavy week follows the heavy week of Elberta. It is not so productive as Elberta or Willett, but considering its other strong points it is sufficiently productive to entitle it to a place among the first rate commercial varieties of the Crawford type.

McKay's Late - A seedling originating on the Van Dusen farm from one of a basket of peaches from William Sharp, of Rock Stream, N. Y., about ${ }_{5} 5$ years ago. It is of the Salway type of peach in appearance and season, varying from October roth to about the 25 th. The fruit from which the cut is taken was picked Oct. I 5 th, and the last picking that year was the $23 \mathrm{~d}$. It is a good producer, seems to be an annual bearer, almost or quite as hardy in the bud as Hill's Chili. In quality it far surpasses the Salway, and is as juicy as the early Crawford. It is a yellow peach with more or less blush in the sun, medium to a bove medium in size. We are planting it on a commercial scale because of itsadaptability to our rather cold location, and because of its extreme juciness and high quality for so late a peach. W. L. M.]

\section{PRICE OF MCKAY'S LATE.}

$\begin{array}{lrrr}\text { Extra size, } 31 / 2-5 \mathrm{ft} \ldots \ldots \ldots \ldots \ldots & 25 \mathrm{C} & \begin{array}{c}\text { Per Doz. } \\ \$_{2} .50\end{array} & \text { Per Hund. } \\ \text { Regular size, } 3-4 \mathrm{ft} \ldots \ldots \ldots \ldots & \$_{20} 0.00 \\ \text { Medium size, } 21 / 2-31 / 2 \mathrm{ft} \ldots \ldots \ldots & 2.00 & 15.00 \\ & & 1.50 & 10.00\end{array}$

Mountain Rose-A large, early freestone peach, yellow nearly covered with a rich crimson; flesh white and excellent quality Follows Alexander and Greensboro, a week or ten days before Early Crawford. This is a very old variety which for the last ten years has been regaining its old popularity, the call for it having increased wonderfully during that time.

Niagara-A large, new peach, native of Western N. Y., said to be of fine quality and great bearer. Judging by the demand for the trees no new variety has been so quickly taken up by peach growers. It is safely among the first four or five variteies in the numbers called for by the market today.

Salway-Medium to large; yellow with rather dull red cheek; flesh deep yellow, rich in quality but rather dry like most late peaches. Extremely valuable commercially, being a good keeper and shipper. October.

Steven's Rareripe-Medium size, high color, very productive, good quality. First of October.

Stump-Very large; creamy white with bright red cheek; flesh white, juicy and good. Last of September.

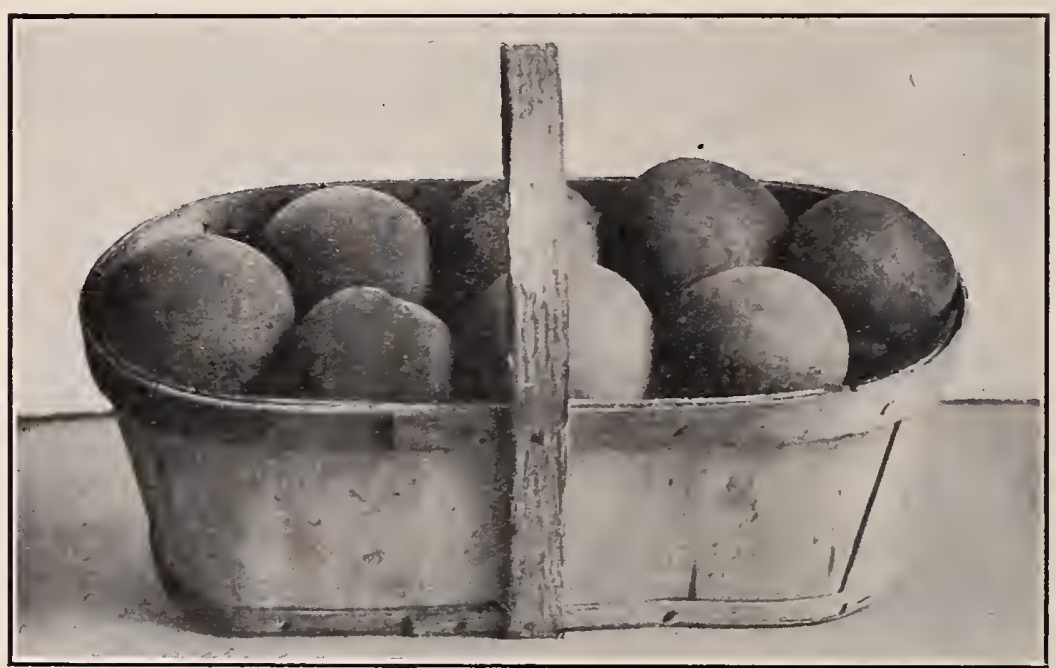

McKay's Late-To introduce this variety and as an inducement to prompt orders, with every order of ten dollars or more, received within the next two weeks, accompanied with the cash, we will add free, six trees of this variety extra size, or nine regular size or twelve medium size, as long as our stock lasts.

\section{IN BEARING YEARS HILL'S CHILI AVERAGES \$225.00 PER ACRE.}


Triumph-Fair size; yellow with red cheek. A late bloomer, escaping late frosts. Ripens with Alexander.

Wheatland-Very large; of the Crawford type in appearance and character. Middle of September.

Willett-The following history and description is taken from the "Year Book" of I 902, by the U. S. Department of Agriculture with colored plates: "Originated from a stone brought from some point in South America by the late Cornelius O'Bryan of "Bryant's Minstrals," who planted it in his garden at No. I Io West 4oth St., N. Y. City, some time prior to I867. Mr. Wallace P. Willett purchased the property in 1874 and that year the tree was in full bearing, carrying several bushels of fruit. The tree survived till I 888 or I 889 . Twelve specimen shown by Mr. Willett at the American Institute Fair in 1874 measured 12 inches in circumference and weighed I 2 ounces each. The following year Mr. Willett put the peach in the hands of Mr. C. L. Van Dusen of Geneva, N.Y., to introduce. Its worth is being recognized in different portions of the North. Its hardiness in the bud, beauty, excellent shipping quality and special adaptability for all purposes make it one of the most promising varieties for the commercial grower. In color it is a rich deep yellow, deeply blushed and striped with crimson; flesh rich yellow, stained with red at the stone, firm but juicy; sprightly sub-acid, quality good." [NOTEWe have given so much space to this variety, feeling that fruit growers will feel an interest in having a rather full history of this great peach. There is one respect in which the description is faulty - it is pronounced by all fruit growers who know it, to be the best in quality of any late peach-it is more than "good"- it is as good as the Early Crawford, although about two weeks later. W. L. M.]

Yellow St. John-Large; deep yellow, dotted with red; melting and juicy with a rich flavor. One of the earliest yellow peaches, rapidly increasing in demand. August.

The "Peach" Collection-A succession of the best varieties for home use. One of each extra size, ${\text { SI.25, regular size, } \text { S }_{\text {. }} \text {, }}$ Champion, Yellow St. John, Mt. Rose, Early Crawford, Elberta, Lamont, Willett, Hill's Chili, McKay's Late
We also have a few hundred small trees, "whips," about $2 \mathrm{ft}$. at $\$_{3} .00$ per 100 , of the following varieties only; these are nice trees and a bargain.

$$
\begin{array}{lll}
\text { Alexander } & \text { Mt. Rose } & \text { Stump } \\
\text { Niagara } & \text { Wheatland } & \text { Elberta. }
\end{array}
$$

\section{GRAPES}

Grapes like peaches require a warm, loose, well drained soil. Plant in rows 6 to $8 \mathrm{ft}$. apart and 6 to I $2 \mathrm{ft}$. apart in the row, according to the habit of growth of the variety.

The grape is pruned, Ist. to reduce the wood and so improve the fruit. $2 \mathrm{~d}$. To keep the vine in manageable shape. In pruning it must ever be in mind, that the fruit is borne at the base of shoots of this year's growth which spring from last year's wood. Another important fact to be remembered is that a vine must be limited to a certain amount of fruit- 5 pounds is a good average. This means that a vine can bear but from forty to sixty clusters. A shoot usually bears two clusters of grapes, therefore from 20 to 30 buds must be left on each vine. This is usually done by having either two or four canes to a vine each cane bearing from six to ten buds. Pruning, then, consists of cutting out all wood excepting canes to set the shoots for as many and no more bunches of fruit than a vine should bear.

Another essential in pruning the grape is to keep the bearing wood near the trunk of the vine. To secure this end new wood must be brought out from the trunk from time to time. The two common methods are, renewal by canes, and renewal by spurs. By the first is meant the bringing out of new canes from year to year from the main trunk. In the second, permanent arms are established upon which short bearing spurs are left- the shoots never becoming canes. Cane renewal is most commonly practiced.

There are a number of styles of training grape vines, all modifications of three chief systems, viz.: The upright, the drooping and the horizontal. In the upright, the trunk is carried to the lowest wire of the trellis; the canes, usually two, are then laid to right and left on the lower wire, and the shoots are tied, or they grow, to the wires above. In the drooping systems the trunks

\section{OUR GRAPE AND BERRY COLLECTIONS, 54 PLANTS, I4 VARIETIES, \$2.00.}


are carried to the top wires, canes laid to right and left, and the shoots allowed to hang down. In the horizontal systems the shoots run to right and left from vertical canes. The two first systems are most used and there is much controversy as to their comparative merits. In general, the upright system is best for the slender, short growing varieties, and the drooping for the strong-growing sorts.

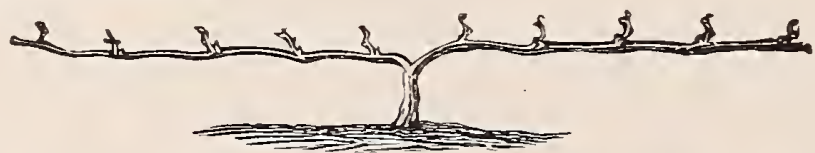

Showing "Renewal by Spur" System

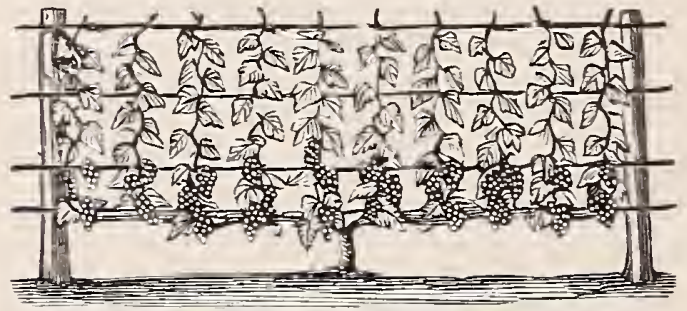

GRAPE-Properly Trimmed

The vines, one or two years old, are planted in late fall or early spring. At planting, cut back to three or four buds, of which but the strongest should be allowed to grow. The second year this cane should be cut back to the same number of eyes as at first. This pruning is to simply delay bearing one year longer and let the plant become established and strong. Again allow but the strongest shoot to grow through the season, at the end of which it may be allowed to form the permanent trunk reaching the bottom or top wire as the case may be. The time to prune is late winter, though some summer pinching back is required.

The third year allow two canes or arms-or four if you have four-to grow from the main trunk, fastening them right and left to the lower wire of the trellis. The following spring, at each eye on these arms will grow new shoots at the base of which will be borne the fruit. This same year see that two more arms are grown to take the place of the two that this year support the fruit bearing shoots, which will be cut away next winter. $\mathrm{Be}$ sure and start these new arms as near to the main trunk as possible so as to keep the vine compact. These directions are for the "renewal by cane" system.

The "renewal by spur" system is illustrated in the cut. The arms are permanent, and each winter the preceeding seasons fruit bearing shoots are cut back to one or two eyes, from one of which comes the shoots that are to bear next season's fruit. By this method the tendency is toward the gradual elongation of the spur from which the new wood comes and the consequent lifting of the bearing wood above the permanent arms.

$\begin{array}{lllr}\text { Strong two year vines } \ldots \ldots \ldots \ldots & \text { Each } & \begin{array}{r}\text { Per Doz. } \\ \text { I }\end{array} & \text { Per Hund } \\ \text { Strong one year vines } \ldots \ldots \ldots \ldots & & \text { I.00 } & 6.00 \\ \text { Stron } & & 6.00\end{array}$

In the following list we include only those that we consider most desirable for family use, taking into consideration quality and productireness and giving length of season. The lists are arranged in order of their ripening.

\section{BLACK OR - RED. WHITE}

Champion Brighton Pocklington

Early Ohio Salem Empire State

Eaton Delaware Moore's Diamond

Moore's E'ly Agawam Niagara

Worden Iona

Concord Catawba

Isbaella

Lakeside Collection-One each of the following six varieties, 2 yr. plants, $50 \mathrm{c}$.

Moore's E'ly Worden Concord

Brighton Delaware Niagara

ROSE BUSHES FOR TEN DOLLARS? WRITE US.

WOULD THIS PROPOSITION INTEREST YOU-IOO 


\section{STRAWBERRIES.}

Plant on soil that has been cultivated two years; work land to a fine condition and compact with roller; trim roots to about three inches; in garden if cultivation is by hand, rows two feet apart will suffice, but for field culture at least 30 inches apart for "hedgerow" culture, 42 inches for matted rows. The former is recommended; in this method plant 30 by 30 inches, cultivate both ways till runners start; let about 4 plants grow in the rows between each two planted, and cut off all other runners, making a thin row with plants about 6 inches apart.

Plant so that the crown is just above the surface, so that rains will not wash the soil into it and check its starting. Cultivate thoroughly and till late fall; mulch well in winter; fertilize heavily.

Delivered by mail anywhere in the United States, post paid, 500 per doz., $75 \mathrm{c}$ per 25 , S1.00 per 50, \$1.2 5 per ioo.

Delivered by express, prepaid, to any point in New York State, $\$_{4} .00$ per $500, \$ 6.00$ per 1000. Thousand rate only on orders of one thousand or more. On especially large orders write for special rates f. o. b. shipping point.

Varieties marked $(\mathrm{P})$ have pistillate or imperfect blossoms, and must be planted near a variety marked (S), indicating that it is a staminate variety, or one having perfect flowers.

Our strawberry plants are grown for us by the very best strawberry grower in the state. His plants and packing are both strictly fancy. Until receiving plants from him we had discontinued the strawberry trade entirely, but have resumed it solely because of shipments made to us for our own use. He is a specialist in this line and can grow much better plants than we can. We recommend the following varieties, but can furnish almost any variety and shall be glad to quote you any others desired.

Beder Wood (S) early and Brandywine (S) medium and medium.

Cardinal $(\mathrm{P})$ midseason

Early Beauty (S) extra early Fairfield (S) extra early.

Gandy (S) late.

Marshall (S) midseason

Miller (S) medium, late

Parson's Beauty (S) Midseason.

(S) Mid-

Senator Dunlap medium.

Splendid (S) midseason

William Belt (S) medium to late.

late.

Climax (S) early.

Glen Mary (S) midseason.

Michael's Early (S) extra early. New York (S) medium to late.

Sample (P) medium to late.

Steren's Late Champion (S) very late.

"Three W" (S) early, midseason and late; a season of five to six weeks.

Young's Early Sunrise (S) extra early.

\section{RASPBERRIES AND BLACKBERRIES.}

IVe cheerfully make acknowledgment to the New York Agricultural Experiment Station for valuable information in their bulletin No. 278 , May r 906 , by Mr. O. M. Taylor, Foreman in Horticulture, as to hardiness and comparative desirability of varieties in these two classes of fruit.

We list mainly only varieties that have proved sufficiently hardy to warrant planting in this locality, and also that have come up to the test for actual merit. The result of their test on these varieties corresponds closely to our own experience, for of the varieties we describe we have grown on a commercial scale all the raspberries except Mills, and all the blackberries except Eldorado and Lawton. In descriptions of these varieties we follow those given in bulletin 278 .

Our Blackberries and Raspberry plants are done up in bunches of 6,12 and 25 ; please let each variety be ordered in these numbers or their multiples.

\section{WE ARE APT TO THINK OF THE SMALL FRUITS LAST--THEY ARE FIRST IN IMPORTANCE.}




\section{RASPBERRIES.}

Raspberries do well on any good, dry soil.

Plant in rows 6 to 8 feet apart according to strength of growth of the variety, and plants 3 to $31 / 2$ feet apart in the row. We advocate the width between rows so as to be able to work the ground with a team, and also to drive through with a wagon to remove brush and to apply fertilizer. It will save you enough labor, if planting on a commercial basis, to more than pay for the use of the extra land. Of course in the garden, much closer planting will be allowable.

Each winter cut out the old bearing canes of the previous season.

Cultivate very thoroughly, and especilly if crop is being affected by drouth cultivate every day to conserve moisture.

Strong one year plants, 5oc per doz., $\$ 3.00$ per 100 .

Cuthbert-Red; without question the best red berry grown for both home and commercial purposes. Its season with us opens from July 6th to Ioth, closing August $r$ st to 7 th. Requires a fairly heavy soil, but with this limitation, does well generally over the state. It has about all the favorable points that can be ascribed to any red berry; the plant is very hardy and vigorous, very productive, the berry is very large, perfect in color, firm, is a "main crop" berry and the very highest in quality of all. \$ 5.00 per I000.

Columbian-A purple variety, believed to be a hybrid of Cuthbert and Gregg. It has the plant of the black varieties and the fruit of the red except in color which is a compromise between the two. The plant is hardy and an enormously strong grower, necessitating wide planting. We advise 8 by 3 ft., certainly not closer than 7 by 3 . Very productive, fruit larger than Cuthbert, easily picked, and like Cuthbert, is wanted extensively for canning. It is a few days later than Cuthbert and the season closes about the same time or a little earlier. $\$ 20.00$ per 1000 .

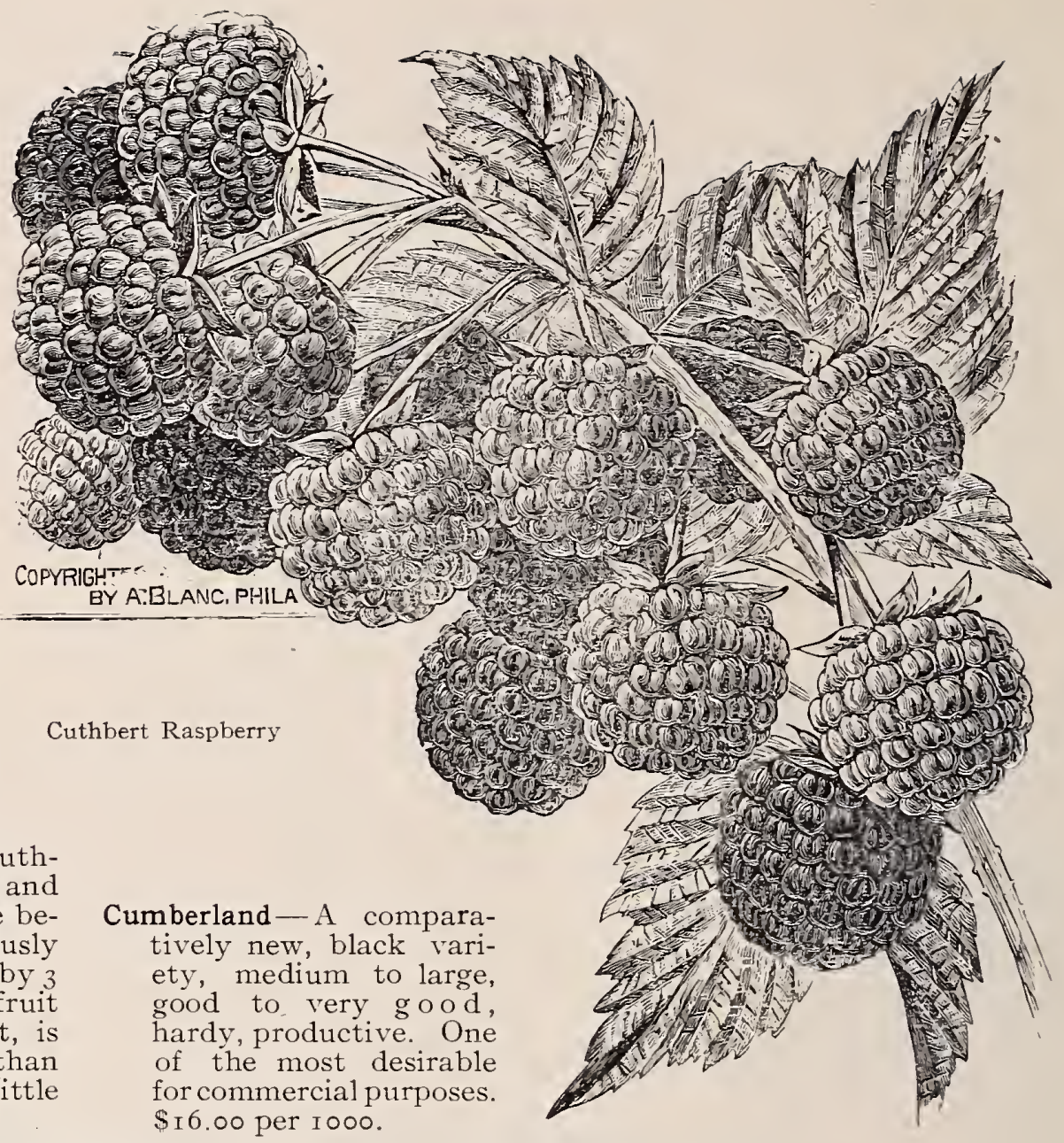

\$1 6.00 per 1000 .

CUTHBERT, 4 ACRES, RELIABLE AS MONTMORENCY, \$200.00 PER ACRE EVERY YEAR. 
Golden Queen-The best yellow variety; vigorous, hardy, productive; fruit large, light yellow, soft, juicy, fairly good quality. It is worthless commercially, but every collection should include a few plants. \$25.00 per rooo.

Gregg-Black, with decided bloom; plants vigorous, hardy, productive; very large size, firm, sweet, high quality. We regard this the best all round black cap. particularly for home use and local markets. \$I 5.00 per Iooo.

Loudon-Red, probably a cross of Turner with Cuthbert. Plants shorter, more stocky and less vigorous than Cuthbert, hardy, productive, fruit nearly as large as Cuthbert, good color, quite firm, not its equal in quality but in many sections it is a standard main crop commercial variety. \$ 8.00 per Iooo.

Marlboro-Red, very early; plants dwarfish, not vigorous, but is hardy and productive; fruit large, bright red, firm, fairly good, inclined to be crumbly; by all means grow it for early home use and for local early market. \$1 5.00 per iooo.

Mills--Black, a seedling of Gregg crossed with Tyler; plants very vigorous, practically hardy, productive; fruit above medium to large, a dull black with considerable bloom; good quality; a very desirable commercial variety. $\$ 20.00$ per I000.

Shaffer-Purple; very similar to Columbian in plant and berry, but with enough difference to prove its distinctness; fruit slightly larger, softer, and lighter purple than Columbian and less productive. $\$ 25.00$ per I 000 .

Garden Collection-Six each of the following varieties, $75 \mathrm{c}$. Cuthbert Columbian Golden Queen Gregg.

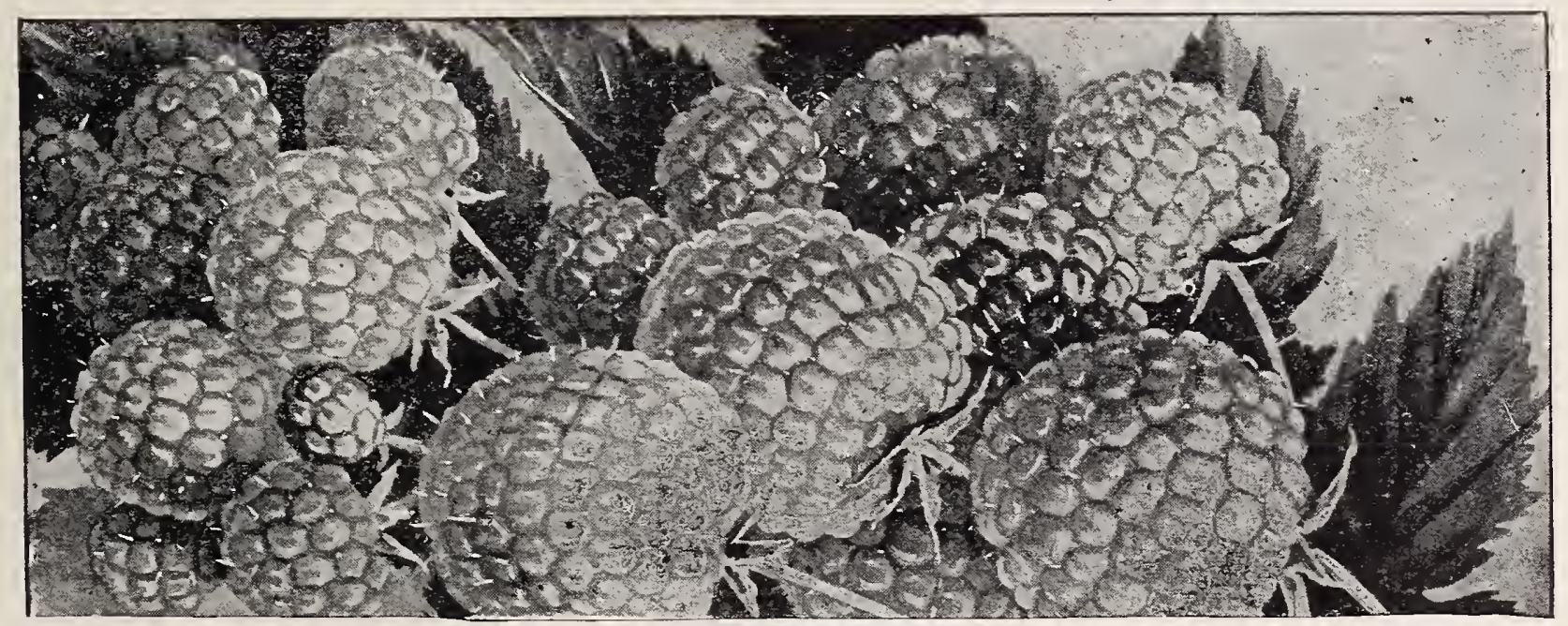

Columbian Raspberry

SCALECIDE IS THE BEST OF ALL PREPARED OIL INSECTICIDES-TRY IT-WE SELL IT. 


\section{BLACKBERRIES.}

Will thrive in almost any well drained soil. Plant in rows 7 or $8 \mathrm{ft}$. apart, plants $3 \mathrm{ft}$. apart in the row. Pinch back canes at 3 to $4 \mathrm{ft}$. and each winter cut out the past seasons bearing canes.

Strong one year plants, 5oc per doz., \$3.00 per Ioo.

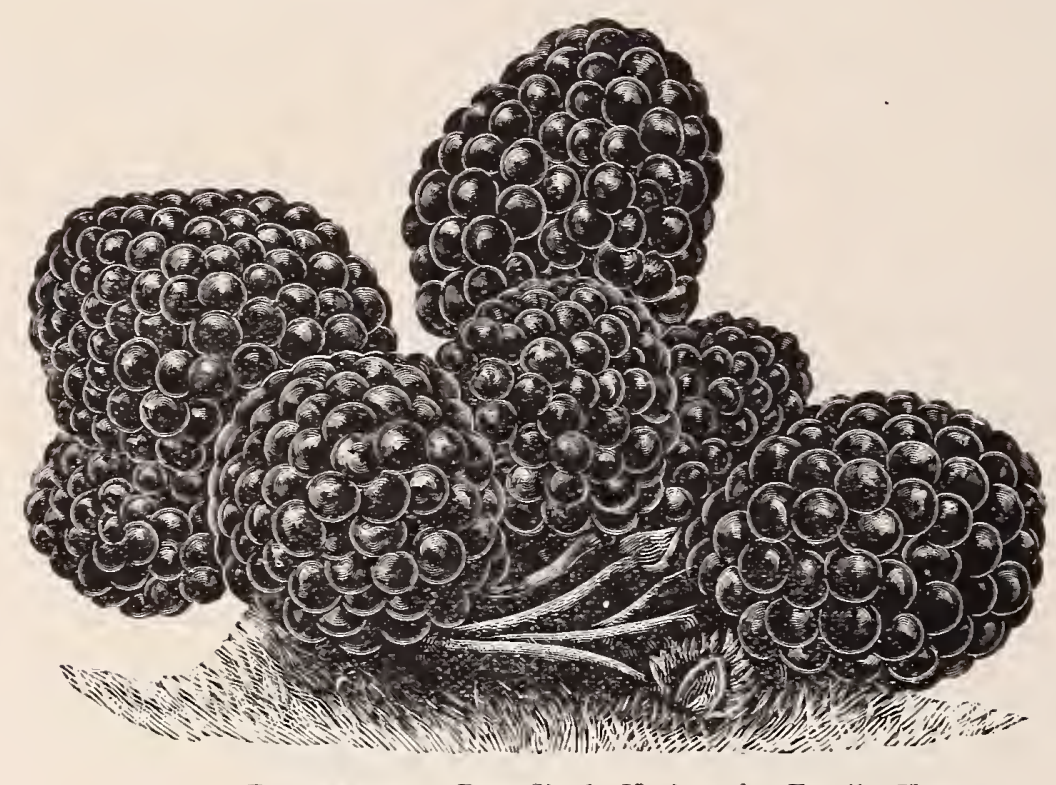

Agawam BlackberRy.-Best Single Variety for Family Use

Agawam - Plants very vigorous, quite hardy, very productive; fruit above medium, bright black, slightly elongated, mild, good to very good. Has a good record commercially. A very long season, extending from early to late. \$i 5.00 per I000.
Ancient Britain-Plants quite vigorous, very productive. quite hardy; medium size, slightly elongated, good black color, mild, good to very good, late. $\$ 20.00$ per 1000 .

Eldorado-Plants moderately vigorous and productive, very hardy; fruit medium to large, roundish, sweet, juicy, color good, mild, good to very good. Has made a good record commercially. Early. \$25.00 per roo०.

Lawton-(New-Rochelle)-Plants vigorous, stocky, quite hardy, productive; fruit medium to large, slightly elongated, attractive black color, nearly sweet, good. \$I 5.00 per 1000 .

Minnewaski-Plants fairly vigorous, not hardy, moderately productive ; fruit large, slightly elongated, sweet, juicy, good. A fine berry but too tender to stand our locality well. Early. $\$ 20.00$ per I000.

Snyder-Plants very vigorous, the hardiest, productive; fruit medium, roundish, color apt to be unattractive unless fully ripe, juicy, good. A standard commercial variety on account of its great hardiness.

Taylor-Plants very vigorous, hardy, not very productive; fruit medium, slightly elongated, sweet, very good. About two weeks later than Snyder. \$I 5.00 per Iooo.

Wauchusetts - Plants vigorous and one of the hardiest; fruit medium, slightly elongated, juicy, sweet, good quality. It is less productive here than most of the above varieties, but we have seen this fruiting very heavily in the eastern part of the state. $\$_{20} 00$ per 1000 .

Lucretia Dewberry-(Trailing Blackberry)-Plants perfectly hardy, remarkably productive; flowers very large and showy; fruit very large, soft, sweet, luscious, without a hard core. This should be in every garden collection, and we do not see why it is not valuable to grow for a nearby market. \$25.00 per 1000 .

Blackbird Collection-Six plants of each of the following, $75 \mathrm{r}$. Agawam Ancient Britain Snyder Taylor.

WE HANDLE THE ONLY SPRAYER DEVELOPING HIGH POWER WITHOUT MACHINERY. 


\section{GOOSEBERRIES}

Plant on any good dry ground, from + by $+\mathrm{ft}$. to $5 \mathrm{by} 5 \mathrm{ft}$. Very little trimming is required.

Industry-An English variety probably best adapted to our climate of any, but still somewhat liable to mildew; fruit very large, good for culinary use when green and a fine dessert fruit when ripe; a brilliant, showy red, very handsome and wonderfully productive. This should be in every collection, but we would not advise its planting on a commercial scale. $25 \mathrm{c}$ each, $\$ 2.50$ per doz.

\section{AMERICAN VARIETIES - Will not mildew.}

I5c each; \$r.50 per doz; \$ro.00 per roo. Except as noted.

Downing-Fruit medium size, roundish, light green, smooth; flesh soft, juicy and good; vigorous and very productive. This is the leading variety in commercial use.

Houghton-Fruit almost medium size, smooth, red, tender, very good; A good cropper.

Pearl-Comparatively new; an exceedingly prolific variety that has been well tested and ranks No. I in vigor and productiveness; fruit about same as Downing, but larger and more productive. $25 \mathrm{c}$ each, $\$ 2.50$ per doz.

Red Jacket-Large, smooth, prolific, best quality, beautiful red when ripe; a wonderful cropper. $25 \mathrm{c}$ each, $\$ 2.50$ per doz.

Smith's Improved-Large, oval, light green, with bloom; flesh firm, sweet and good. Very vigorous.

\section{CURRANTS.}

Commercially we advise planting 5 by $5 \mathrm{ft}$, so as to cultivate both ways. Trim each year, thinning out the old wood, and preserving the more vigorous young shoots.

Ioc each, \$1.00 per doz., \$7.50 per roo, except as noted.

Black Champion-Vigorous and productive; probably the best of the black varieties.

Cherry-Very large, deep red berries, in rather short, heavy clusters, acid; plant very vigorous and productive.

Fay's Prolific-Color deep red; great bearer, clusters longer than Cherry and more thicklyborne on the branches. Sweeter than
Cherry higher quality and several days earlier. Does not hang long after ripening.

Perfection-New, a cross between Cherry and White Grape; color bright red, large size, very productive, clusters very long, size of berry being maintained well to the end quality good. [NотE-We fruited this for the first time this season, and are very favorably impressed with it. The clusters hung in ropes about the stems. We believe it is a very valuable variety. W. L. M . 2 oc each, $\$ 2.00$ per doz.

White Grape-Large, yellowish white, sweet, excellent quality, valuable for table use; vigorous and productive.

White Imperial-A new white currant quite similar to the last, with perhaps larger berries, not so heavily clustered; very clear, transparent yellow or ecru in color, very sweet, and of high quality; fairly vigorous and productive.

Wilder-Red, and as a commercial variety today stands at the top. The plant is vigorous and productive to the highest degree; like the Perfection the clusters hang so thick on the bush that there is not room for any more. It is good size in both berry and cluster, good quality and color, firm, a fine shipper, and if when it ripens you are not ready to pick you can leave it a couple of weeks or more without deterioration. It is a wonderful currant.

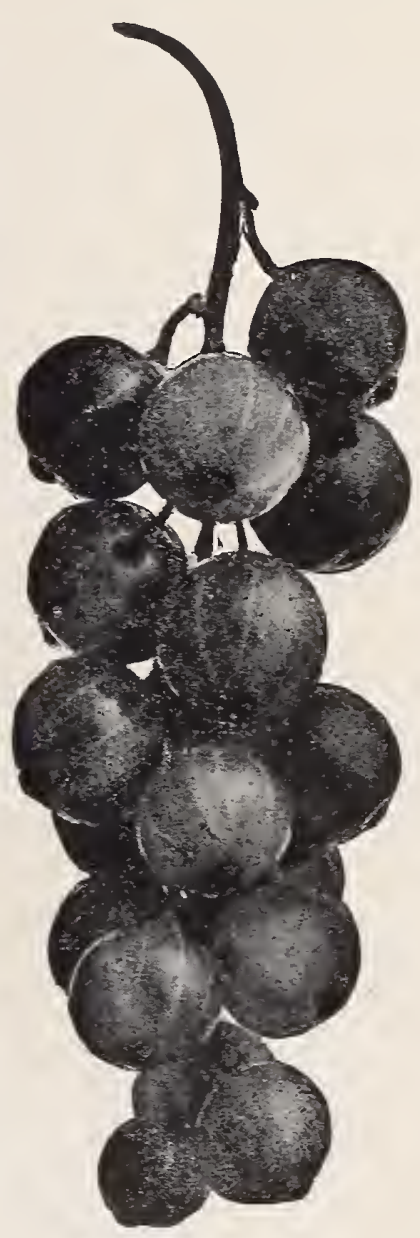

PERfECTION CURRANT

THE BORDEAUX AND BORDEAUX-LEAD PASTES WILL SAVE YOU LOTS OF TROUBLE. 


\section{ASPARAGUS.}

Rows five feet apart, plants one foot apart in the row. Plant a foot deep, covering roots two or three inches, and as the plants grow gradually fill in around them. Fertilize as liberally as possible.

Two and three year plants, Sr.00 per I00. \$6.00 per rooo. Barr's Mammoth-A new variety which on light soil has proved the most productive of these three rarieties.

Conover's Collossal-A standard variety which till the introduction of the other two described here, stood alone as the best.

Palmetto-A new variety, generally proving more productive than Conover's.

All the above are similar and first class in quality, ther are green varieties and all valuable both for the garden and for growing on a large scale.

\section{RHUBARB. - IOc each. \$I.00 per doz.}

Myatt's-Early, very large, tender and delicate flarored; requires less sugar than the more acid sorts.

Victoria-An old variety, a very rank, strong grower, stalks attaining great size under high cultivation.

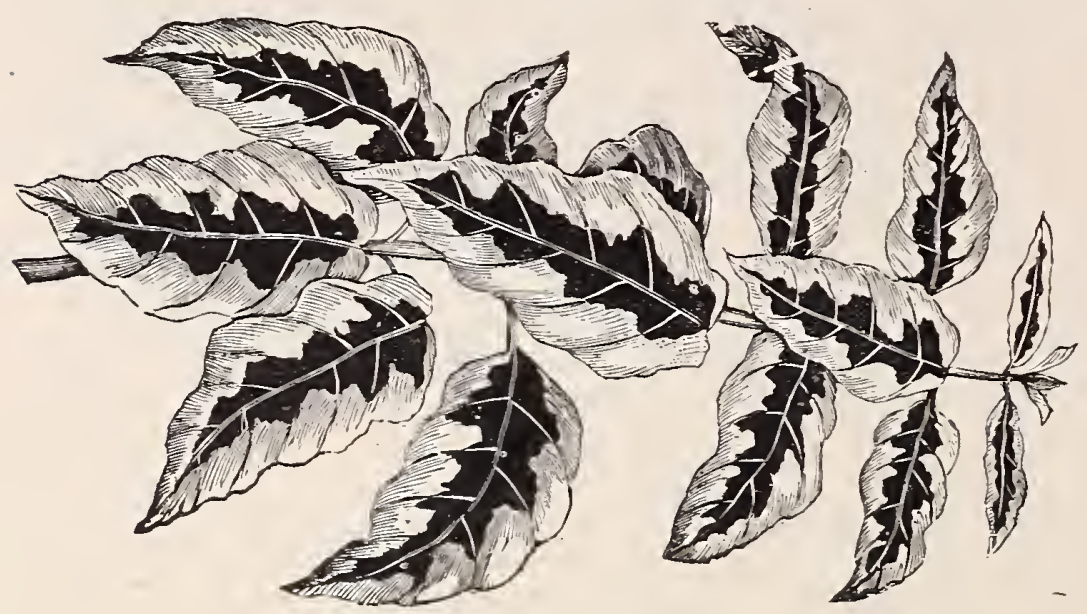

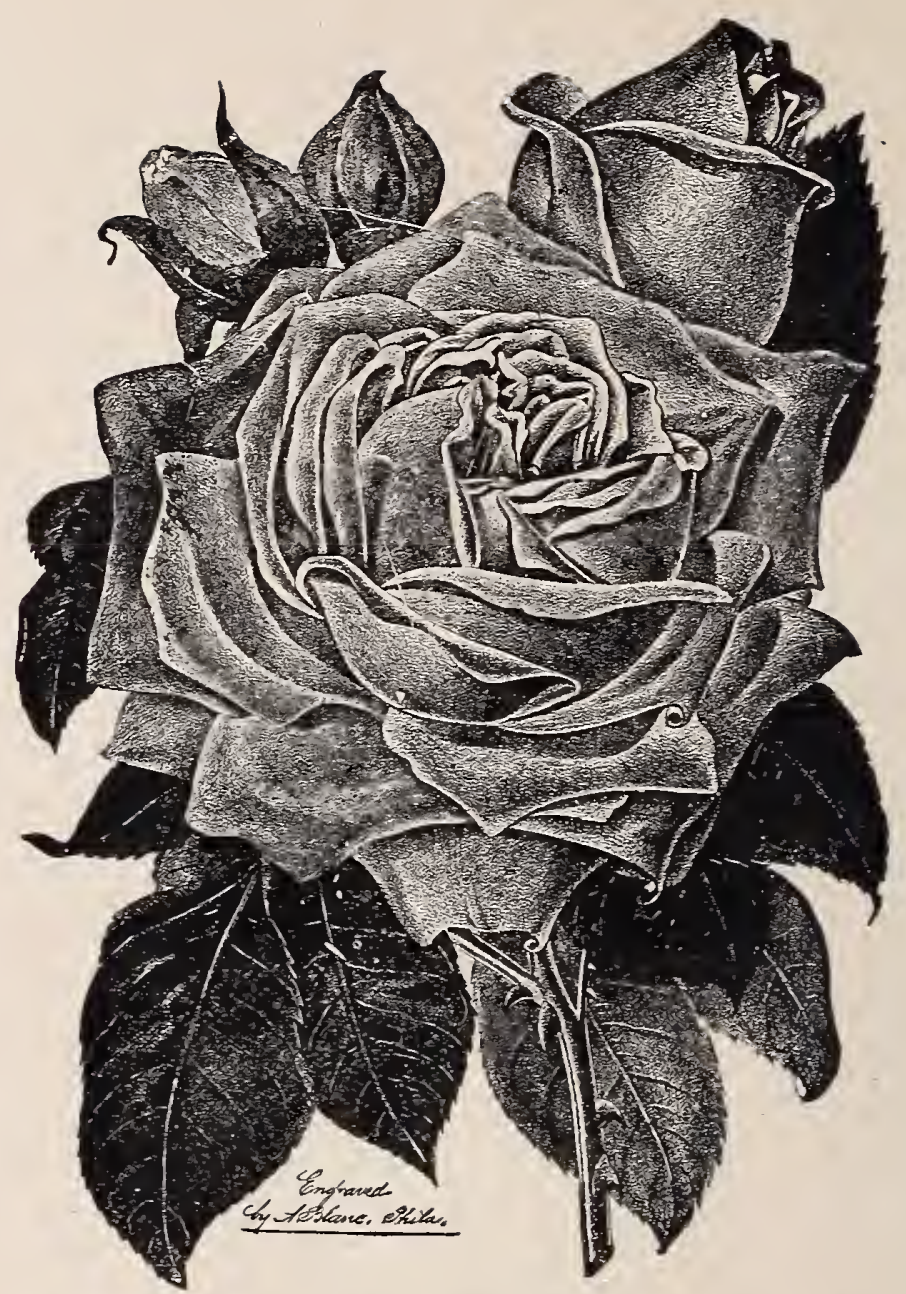

Madame Gabriel Luizet.-Best Pink Rose, much Reduced

WE CAN FILL ORDERS AS LATE AS THE FIRST WEEK IN MAY, AND IN ROSES TILL JUNE.

Vartegated-Leaved Wegelia 


\section{ORNAMENTAL DEPARTMENT}

We are not large ornamental growers, confining ourselves mainly to Roses, and the leading ornamental trees and hardy shrubs. We are however in close touch with the best ornamental specialists in the east, and can supply almost everything in the ornamental line desired. Any fuller information than given here we shall be very glad to supply on request.

Single rates only are given, the dozen rate always being ten times the single rate. Special quotations on large quantities.

\section{ROSES-25 Cents Each.}

Plant in very rich, mellow soil, fertilize with well composted manure only. When set cut to a few inches of wood only. Thereafter, cut back almost to the ground each year, except on ramblers and climbers, which trim according to the space you wish them to cover. Ramblers and Hybrid Perpetuals bloom on this year's wood, hence must be cut to keep them making new wood to produce bloom; the Climbers bloom from last year's wood as also the Persian Yellow, so they must not be so closely pruned. All roses want lots of sun-give them frequent cultivation, severe pruning and the sunniest place you can and you can grow roses.

With exception of a few varieties which are never grown on their own roots, all our roses are on their own roots, so that there is no dying out of the top and leaving you a "wild" rose, as is the rule with most roses propagated by budding. Never plant a budded rose if you can get one grown on its own roots. All varieties listed, $25 \mathrm{c}$.

\section{RAMBLERS.}

Very strong growers except "Baby," which is very light. "Baby" is a continuous bloomer, from June till snow flies -is the greatest bloomer of all varieties. All other ramblers offered bloom but once, but very profusely and are all climbing in habit.

Baby Rambler - A continual bloomer, a small deep pink rose, borne in large clustesr.

Crimson Rambler-Crimson, clustered, one plant often producing thousands of blossoms.

Dorothy Perkins-B e a u t iful shell pink, the prettiest of all ramblers, and as free blooming as the Crimson.

Philadelphia Rambler - Very similar to "Baby," but not a continuous bloomer.

Pink Rambler - Pink, semidouble, very delicate.

White Rambler-Same as the pink, except in color.

Yellow Rambler - Very light straw color, otherwise same as pink.

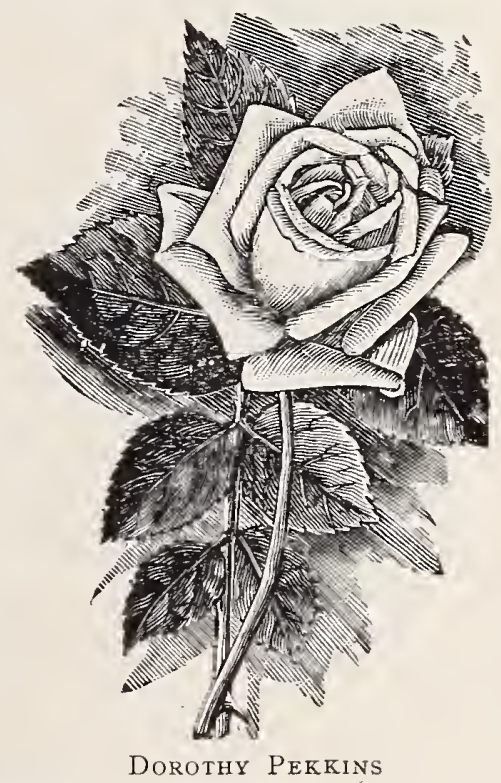

\section{CLIMBERS.}

Baltimore Belle-White with blush center; very fine.

Empress of China-Light pink, semi-double, very pretty.

Gem of the Prairie-Similar to "Queen" except darker, larger and is fragrant.

I2 ORNAMENTALS, TREES, SHRUBS,

VINES, ROSES-OUR SELECTION, \$2.00 
Queen of the Prairie - Bright rose color, large and a free bloomer.

Seven Sisters-Crimson changing to blush, clustered. HYBRID PERPETUALS-Perpetual bloomers.

Caroline De Sansal-Delicate flesh color, vigorous.

Coquette des Alps-White, later blooms having a decidedly flesh tint; except Hermosa the freest bloomer in this class-blooms right up to freez ing time. All things considered we regard this as the best of all H. Ps.

Francois Levet-Cherry red, very fine in bud.

Frau Karl Druschki-(New) - White, one of the finest roses grown.

General Jacqueminot-Brilliant crimson, one of the very best

Hermosa-A hardy pink tea rose, blooms constantly from June till heavy frosts. Next to "Baby" as a free bloomer.

Jules Margottin-Carmine, tinged with pink-free bloomer and vigorous.

John Keynes-Very dark, almost black, vigorous, free bloomer.

Leopold Premier-(New)-Dark crimson, large, free bloomer, one of the best.

Louis Van Houtte-Crimson maroon, large, good bloomer, a very fine variety.

Madam Gabriel Luizet-Pink, large, the best pink rose of this class.

Magna Charta-Very similar to last, larger, not quite so fine.

Marchioness of Lorne- $(\mathrm{New})$ - Rich rose color, a very free bloomer.

Paul Neyron-Pink, the largest bloom of any, fine and vigorous.

Prince Camille De Rohan-Very dark red, similar to Keyne one of the best.

Persian Yellow-Similar to the old yellow "Scotch" rose, but larger and finer. Is a "summer" rose, blooms but once.

Rosebud Collection-Six varieties, one each, our selection, $\$_{1} .00$ Rose Premium-We give a rose bush, our selection of variety, with every order.

\section{HARDY AND ORNAMENTAL SHADE TREES.}

Sizes of ornamental trees will be such as constitute first class trees of the various varieties, running from 3 to $5 \mathrm{ft}$. on such as $\mathrm{Crab}$ and Thorns, to 7 to ro $\mathrm{ft}$. on such trees as Maples and Poplars.

Alder, Imperial Cut Leaf $\$ .75$

Birch, Cut Leaf ...... $\quad .50$

Birch, Purple Leaf .... r.5०

* Crab, Bechtel's Flowering $\ldots \ldots \ldots \ldots \ldots$

* Elm, American......$$
40
$$

Beech, Purple Leaf .... \$ $\$ .75$

Beech, Weeping ..... I. I.00

* Catalpa, Speciosa.. . . .30

Catalpa, Bungeii,

(Dwarf) ........... I.00

.75 Elm, Camperdown, Weep-

ing $\ldots \ldots \ldots \ldots$ r. r.oo

Linden, American (Basswood) ..............

Magnolia, Acuminata . .

Maple, Norway........

* Maple, Wier's Cut Leaf

...... I.00

* Mountain Ash, Oak Leaf .50

Mulberry, New American

* Poplar, Carolina, very good........

Poplar, Silver Leaf ....

Thorn, Double White . .

Tulip Tree

Willow, Common Weep

ing $\ldots \ldots \ldots \ldots$.

* Varieties among the most satisfactory, hardy, and very popular everywhere. We recommend them for all ordinary lawn and shade purposes.

THE NIAGARA PREPARED LIME-SULPHUR SOLUTION EQUALS THE HOME MADE-WE SELL IT. 


\section{EVERGREEN TREES.}

Most varieties about $2 \mathrm{ft}$., or 2 to $3 \mathrm{ft}$.
Arbor Vitae, American

Arbor Vitae, Pyramidalis

Fir, Balsam.

Fir, Nordman's

Spruce, Koster's Blue ..

Spruce, Norway . . . . . . .

Pine, Austrian ........

Pine, Scotch . . . . . . . .

.50
.50
.40
1.00
2.50
.50
.50
.75

Arbor Vitae, Hovey's

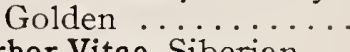
Arbor Vitae, Siberian .

Fir, Concolor Spruce, Colorado Green

Juniper, Irish . . . . . . .

Pine, White
Spruce, Colorado Blue

Pine, Mugho, Dwarf . . .

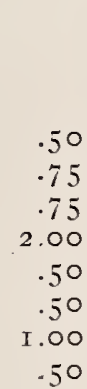

\section{HARDY SHRUBS.}

Almond, Double Flower-

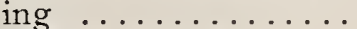

Barberry, Purple ......

Calycanthus ........

Cornus, Red branched.

Deutzia, Crenata

Deutzia, Gracilis, Dwarf

Elder, Variegated. . . . . .

Fringe, Purple

Hydrangea, bush form.

Japan Quince . . .....

Plum, Double Flowering

Snowball, Japan, fine. .

Spireas, red, pink, white, each

Altheas, red, pink, white, .40 .20

purple, variegated leaf Barberry, Japan, new, very fine $\ldots . . . \ldots$. .25 Cornus, (Dogwood)

Elegantissima

Currant, Flowering ..... Deutzia, Double white

Elder, Golden

Forsythia, Viridissima

Fringe, White .......

Hydrangea, Tree form

Lilac, red, white, purple

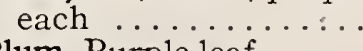

Plum, Purple leaf ....

Snowball, Common ....

Spirea, Golden Leaf . . .

.25

.25 Syringa, Golden Leaf .

Wegelia, red, pink, white each ............... Wegelia, Variegated

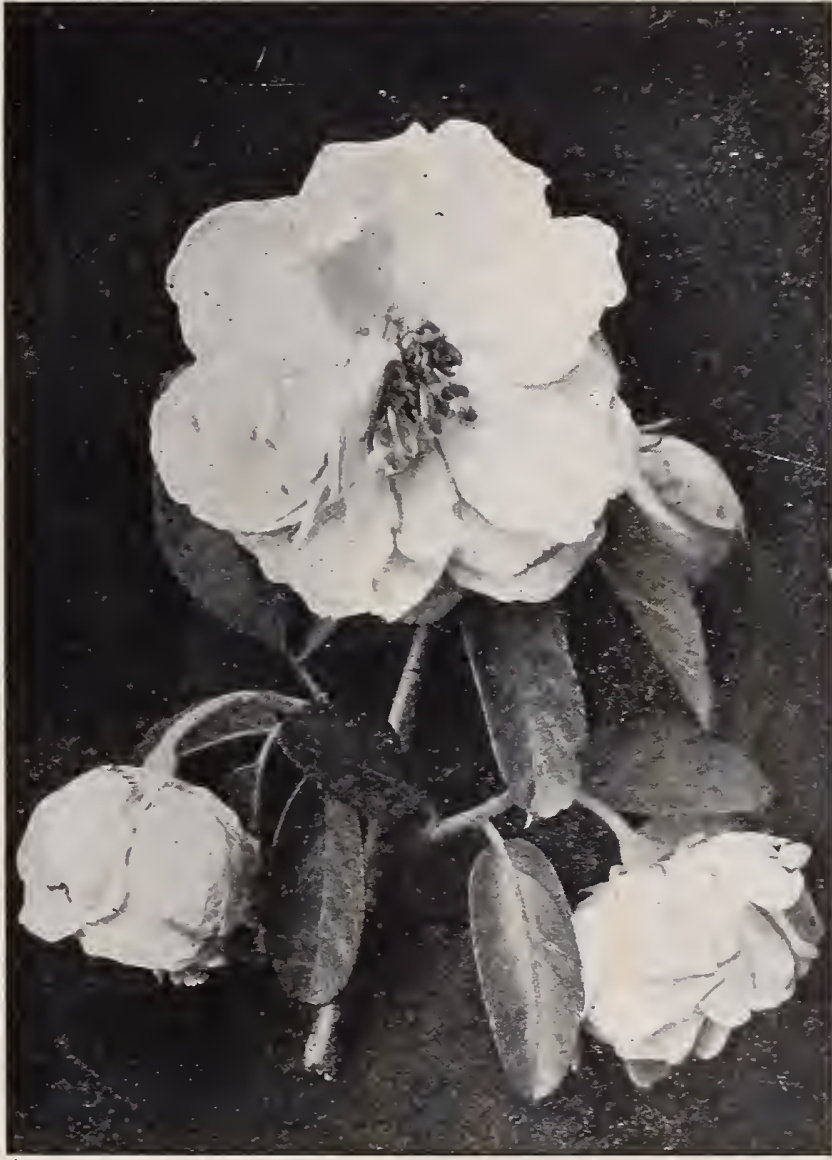

Bechtel's Flowering CRAB.-Imagine an enlarged, double, bright pink apple blossom and you have it exactly. Nothing can be finer.

CAN YOU MAKE A DOLLAR EASIER THAN BY MIXING A TON OF FERTILIZER? TRY IT. 


\section{HEDGE PLANTS.}

Barberry, Japan, (Thunbergii) I 2 to is in.

I0.00

This makes the handsomest lawn hedge

we have ever seen

Californla Privet, I 8 to 24 inches ......... 8.00

Honey Locust, I 2 to 24 inches ......... . . 2.00

Osage Orange, I 2 to 27 inches........... I.00

Norway Spruce, I 2 to I 8 inches ........ 20.00

\section{HARDY CLIMING VINES.}

American Ivy, (Virginia Creeper) . . . . . . . . . . . . . . . . . . . .

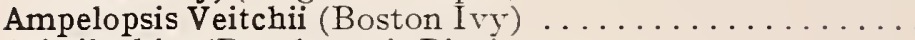

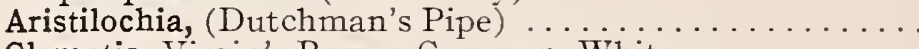

Clematis, Virgin's Bower, Common, White ............

Henryii, White, Large Flowered............

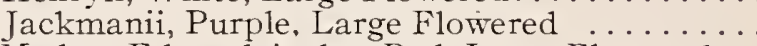
Madam Edward Andre, Red, Large Flowered. .

Ramona, Largest size, Purple ............ Paniculata, Clusters of small, white flowers, fine

Honeysuckle, Hall's Japan, Hardy, free blooming, best

Monthly Fragrant, Hardy, a fine, old variety

Scarlet Trumpet, Fine red, trumpet shaped flowers

Trumpet Vine, Large flowers. $3-4$ inches long, rank grower

S. 25

.25

.75

.25

.50

.50

.50

.50

.25

.25

.25

.25

.25

Wistaria, Chinese varieties, Purple and White, each .....

Paeonias - These beautiful old fashioned plants are among the most satisfactory that can be planted, being sure to give a perfect wealth of bloom every spring, with the least possible care to the grower.

Red and Pink varieties, $25 \mathrm{c}$ each, White, $40 \mathrm{c}$

Dahlias-All colors, mixed varieties, I $5 \mathrm{c}$ each.

Gladiolus bulbs-Assorted colors, 5oc. per doz.

\section{PRICE LIST OF CHEMICALS.}

Prices on Every Item in the Following List are for Remittance with Order either in P. O., or Express Money Order, or in New York Draft.

For the benefit of our customers who have occasion to use Chemicals either as Fungicides, Insecticides or for Fertilizers, we offer the following at prices annexed.

ARSENATE OF LEAD - Insecticide for eating or "chewing" insects; the best insecticide for Coddling Moth on apples and pears; no matter how strong it is used it cannot injure the foliage, while the use of Paris Green, London Purple or White Arsenic compound is always attended with more or less danger to the foliage.

Arsenate of Lead has hitherto been so expensive as to make it practically prohibitive for this purpose, but the great reduction in price this year, taking into consideration its superior effectiveness and the absolute safety of the foliage in its use, is bringing it to the front as the leading insecticide. Use 3 to $5 \mathrm{lbs}$. to 50 gals. water or Bordeaux mixture. For fancy fruit would adrise least. 4 lbs.
$600 \mathrm{lb} . \mathrm{bbls}$.

$300 \mathrm{lb}$. half bbls.

I00 1b. kegs

201 b. cans or buckets $S_{I I .00}$

Io lb. cans or buckets I 2.00

5 lb. cans or buckets I 2.00

I lb. cans

I 4.00
SI0.00 per I $00 \mathrm{lbs}$.

10.00

10.00
Delivered at any station in New York State.
Special Prices on large lots of Arsenate of Lead on application. SCALECIDE-Insecticide for "sucking" insects such as the different scales.

It is fair to compare this remedy with the Lime-Sulphur solution, used for the same purpose. Gallon for gallon Lime-Sulphur costs less, and also has decided, well demonstrated fungicidal properties. Scalecide, however, covers much more surface, gal-

LOOK OVER OUR CHEMICAL LIST- WE MAY BE ABLE TO SAVE YOU SOME MONEY. 


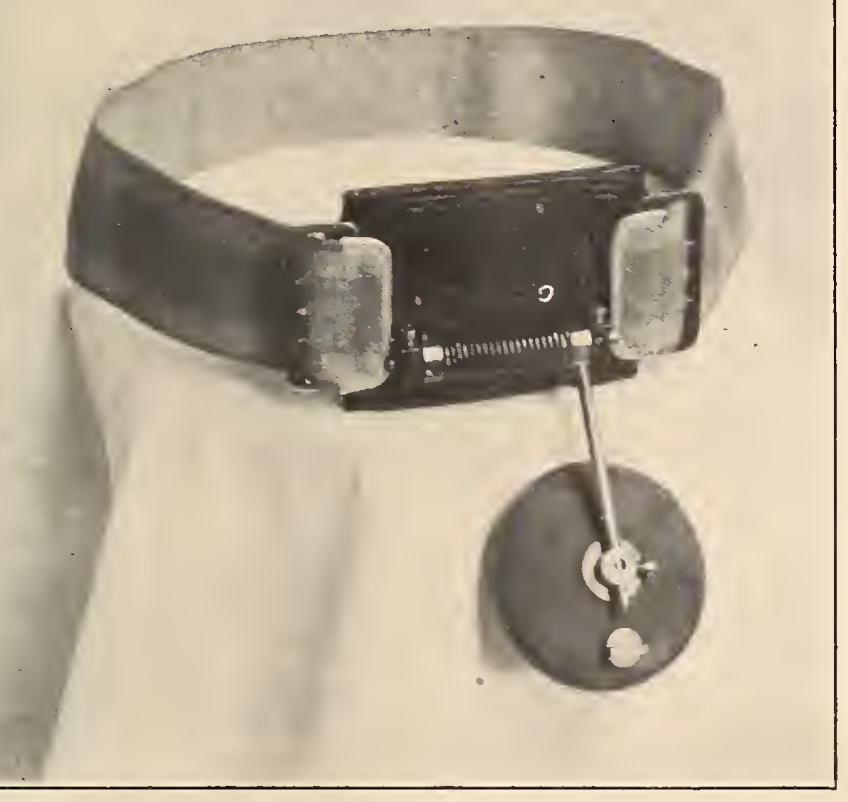

THE cut represents an entirely new

idea in trusses worked out by the inventor to apply to his own needs.

The few in use have given such great satisfaction that we venture to inclose this slip, and if it is of interest to you will be glad to give full information by letter.

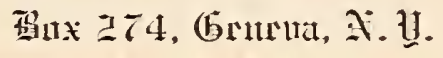



lon for gallon than the Lime-Sulphur, and as, from its oily nature it spreads after touching the tree, it is easier to hit every part of the tree than with Lime-Sulphur which does not spread. Fungicidal properties are claimed for it and seemingly with reason, as it contains sulpho oils besides some free sulphur.

In applying Scalecide it works freer in the nozzles than LimeSulphur; can be made ready for use at practically no cost for labor and reduces very materially the cost of the labor element of spraying.

50 gal. bbls .......\$25.00 30 gal. jacketed tins .. \$15.00 30 gal. bbls ........ r6.00 ro gal. ". " ... 6.00

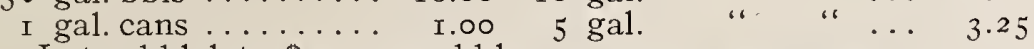

In ten bbl. lots, $\$ 24.00$ per bbl.

One gallon cans sent only by express at your expense.

On 50 gallon lots or over freight is paid to any point east of the Mississippi River, and North of the Ohio River and North Carolina State Line.

BORDEAUX MIXTURE-For fungicide. The following Bordeaux pastes, both with and without the insecticide added, while they cost more than the same mixtures prepared from the chemicals are so convenient in mixing and applying that they are being extensively used. If spraying on a large scale we would advise home preparation from chemicals, but for all limited areas they are highly recommended. They are prepared on the basis of $3 \mathrm{lbs}$. Copper Sulphate and $4 \mathrm{lbs}$. lime to 50 gallons of water, with the addition of $3 \mathrm{lbs}$. lead arsenate for the insecticide.

\section{BOREAUX BORDEAUX-LEAD ARSE-}

In $500 \mathrm{lb}$. bbls $\ldots .5 \frac{1 / 2}{\mathrm{c}}$ per $1 \mathrm{~b}$. In $500 \mathrm{lb}$. bbls $\ldots .8 \mathrm{I} / 2 \mathrm{c}$ per $1 \mathrm{~b}$ In $1001 \mathrm{~b}$. kegs ... 6 6 6 per $1 \mathrm{~b}$. In roo $1 \mathrm{~b}$. kegs ... 9 c per $1 \mathrm{~b}$ In $50 \mathrm{lb}$. kegs ...6 $6 \mathrm{r} / 4 \mathrm{c}$ per $1 \mathrm{~b}$. In $501 \mathrm{~b}$. kegs $\ldots .69 \mathrm{r} / 4 \mathrm{c}$ per $1 \mathrm{~b}$ In ro $1 \mathrm{~b}$. pails ... $7 \mathrm{r} / 2 \mathrm{c}$ per $1 \mathrm{~b}$. In ro $\mathrm{lb}$. pails ... ro $1 / 2 \mathrm{c}$ per $\mathrm{lb}$ One part paste to 49 parts water Ten parts paste to 60 to Ioo gal $\begin{array}{ll}\text { usually recommended, one to } 99 & \text { water according to strength } \\ \text { parts water for peaches. } & \end{array}$ parts water for peaches.

Above prices delivered at any station in New York state in lots of roo lbs. or more. Less than roo lbs. f. o. b. Grasselli, New Jersey, which takes the New York City freight rate.

COPPER SULPHATE-For making the Bordeaux Mixture. In $450 \mathrm{lb}$. barrels, $\$ 5.5^{\circ}$ per roo lbs., or $\$ 24.75$ per bbl. f. o. b. Syracuse, N. Y.

\section{Special Prices on large lots on application.}

(The price of copper Sulphate is subject to constant fluctuations and all orders are taken subject to any advance in price after issuing this list.)
SULPHUR-For use in preparation of Lime-Sulphur mixture an insecticide for "sucking" insects. All $99 \%$ pure and prices f. o. b. New York

Powdered Sulphur (coarse flour) in $275 \mathrm{lb}$. and $375 \mathrm{lb}$. "bbls. \$I.90 per I00 $1 \mathrm{bs}$

Flour Sulphur (fine flour) in $250 \mathrm{lb}$. bbls., \$2.ro per roo lbs.

Flowers of Sulphur (sublimated) in I $501 \mathrm{~b}$. and $224 \mathrm{lb}$. bbls., $\$ 2.35$ per IOo 1 bs.

NIAGARA LIME SULPHUR SOLUTION-Insecticide for scale insects, and fungicide.

In 50 gal. bbls., making 600 gals. of solution ready to use, \$ I I.00 In 30 gal. bbls., " 360 " " " " " " " " 7 " 7.00

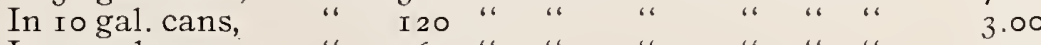
In 5 gal. cans, " " 60 " "

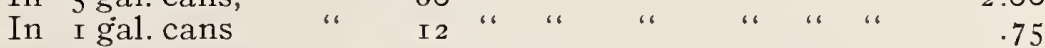

The experimenters' tests of this solution shows that for the same strength preparations, it is equally effective as the home prepared solution. This being vouched for, unless you have enough spraying to do to warrant your fitting up a plant to cook it with live steam, this Niagara preparation is cheaper than you can make it at home. By all means use this solution instead of ever trying to cook it in a kettle.

If other chemicals than those offered are wanted in quantity. we will be pleased to get you the lowest possible figures, on application.

\section{CHEMICALS AND MATERIAL FOR MIXING FERTILIZERS AT HOME.}

\section{YOUR OWN FERTILIZER}

\section{And know what you are getting.}

\begin{tabular}{|c|c|c|c|c|c|c|}
\hline te of Soda & $\begin{array}{c}\mathrm{P} \\
\text { Ammonia. }\end{array}$ & $\begin{array}{l}\text { osphoric } \\
\text { Acid. }\end{array}$ & $\begin{array}{l}\text { Actual } \\
\text { Potash. }\end{array}$ & $\begin{array}{c}\text { Wei } \\
\text { of b } \\
200\end{array}$ & & $\begin{array}{l}\text { Per ton. } \\
\$ 54.00\end{array}$ \\
\hline Dried Blood. & $12 \%$ & & & 12.5 & & 39.00 \\
\hline round Tankage & $8 \%$ & $12 \%$ & & 125 & “‘ & 25.0 \\
\hline Bone Meal ........ & $31 / 2 \%$ & $22 \%$ & & 125 & " & 24.0 \\
\hline Acid Phosphate..... & available & $14 \%$ & & 167 & “ & I 2. \\
\hline 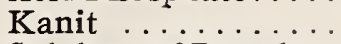 & & & $12 \%$ & 200 & “ & 12.0 \\
\hline of Potash & & & $50 \%$ & 225 & “ & 47.0 \\
\hline Potash. & & & $50 \%$ & 225 & "، & 41.5 \\
\hline
\end{tabular}

F. O. B. Buffalo, N. Y., in any quantity desired, from one bag up. 


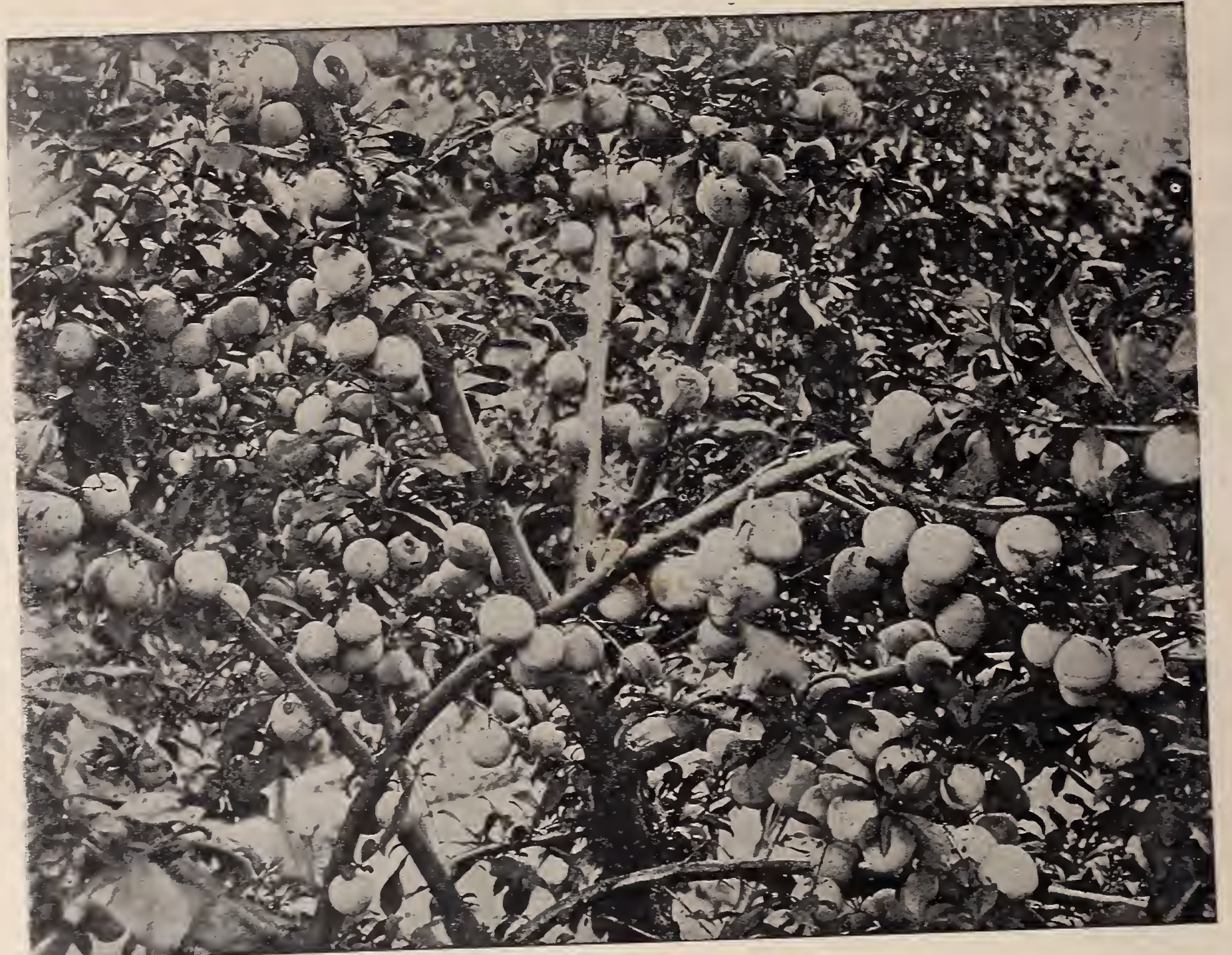

